\title{
Remedial Education Programs to Accelerate Learning for All
}

\author{
Analice C. Schwartz
}

GPE Working Paper Series on Learning, No. 11

May 1, 2012 


\section{Acknowledgements}

This paper was written by Analice C. Schwartz for the Global Partnership for Education (GPE), formerly known as The Fast Track Initiative, under the guidance of Helen Abadzi (Senior Education Specialist at the Global Partnership for Education). Special thanks to Collette Chabbott (The George Washington University) who provided valuable insights and comments of earlier drafts. The paper also benefited from feedback from World Bank's country officers, education specialists, and selected program developers.

The findings, interpretations, and conclusions expressed in this work are of the author's only and do not necessarily reflect the views of the GPE, the World Bank, its Board of Executive Directors, or the governments they represent.

Cover picture by Masae: Pupils writing on the blackboard in a village school in Laos, December 9, 2007 


\section{Table of Contents}

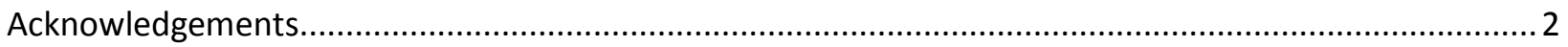

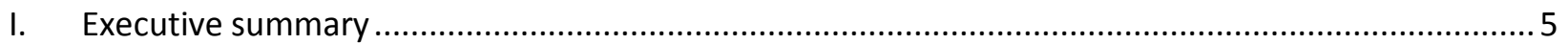

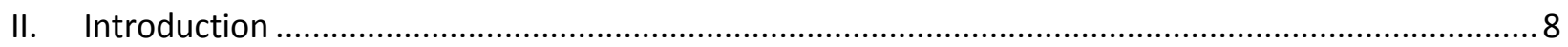

What are the specific design features of remedial education programs? ........................................... 8

How remedial programs differ from accelerated or complementary programs? .............................. 9

How should these programs be implemented, and does it matter when remedial efforts start? ...... 9

Remediation to Meet Education Sector Strategies .......................................................................... 9

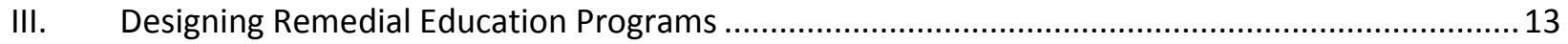

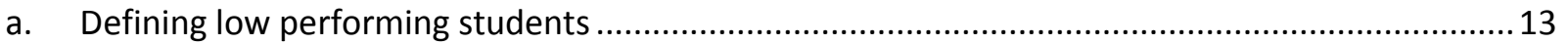

b. Defining remedial intervention goals based on learning needs .............................................. 14

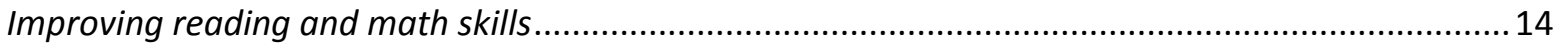

Providing an alternative to grade repetition and avoiding drop out ............................................. 14

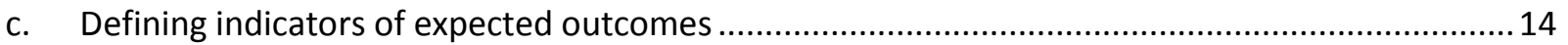

Prepare participants for reintegration in the regular classroom or to move to another level ...........15

IV. Implementing and Delivering Remedial Programs ….............................................................. 16

a. Modes of Implementation and Delivery .................................................................................. 17

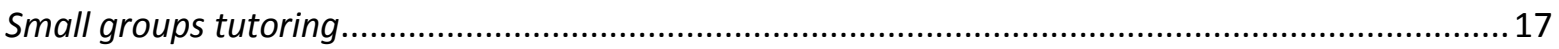

Separate classrooms for low performing students ...................................................................... 17

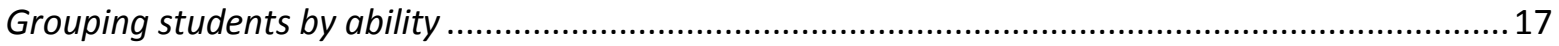

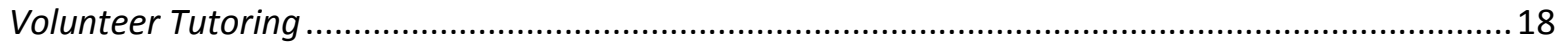

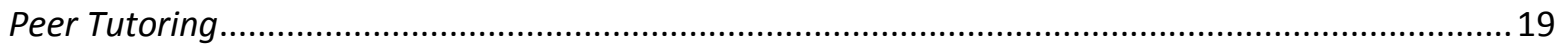

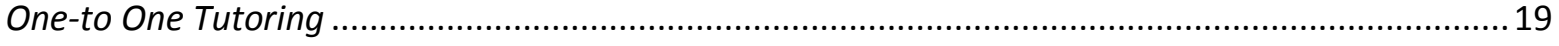

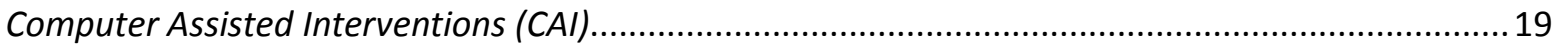

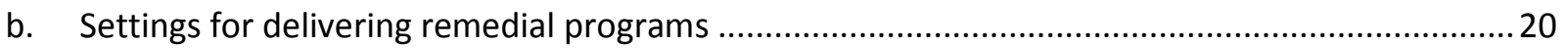

Remedial Education during school hours - curricular ................................................................... 20

Remedial Education after school hours - co-curricular and extra-curricular ....................................22

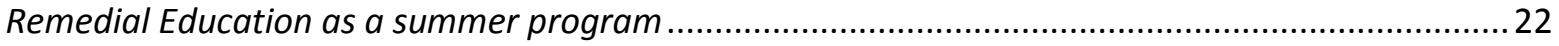

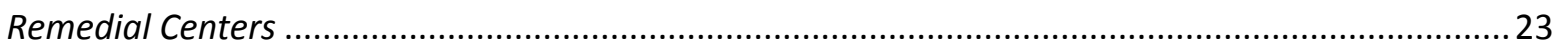

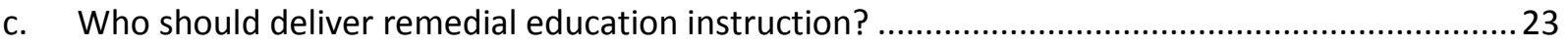

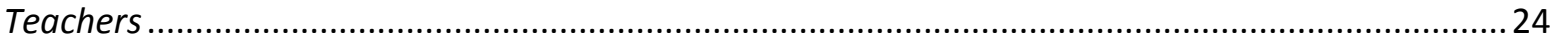


d. What types of training for teachers and school administrators are needed for effective delivery of remedial education?

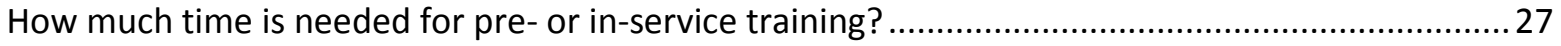

How to plan for support, monitoring and evaluation? ............................................................... 28

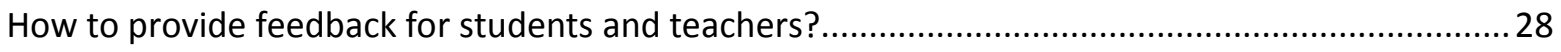

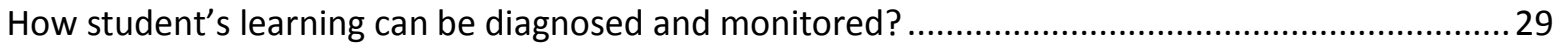

e. What does the evidence suggest about remedial education and interventions to improve literacy and numeracy in low income countries?....

f. What have we learned from remedial interventions that may have contributed to better education outcomes?.

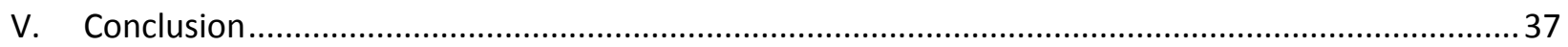

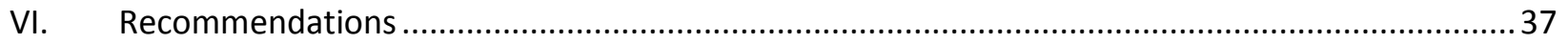

References

Annex QQ. Linkage between Remedial Education Programs and Education Strategies of Multilateral and Bilateral Agencies

Annex RR. What can be learned from Remedial Education Approaches in the Unites States? .51

Annex SS. Remedial programs for out-of-school/over aged children ...................................................5

Context.

Examples of Remedial Programs for Out-of-School and "Over aged" Children

Annex TT. Country examples of remedial programs -..... .55

India - Accelerated learning support classes to improve reading and math in the early grades ...........55

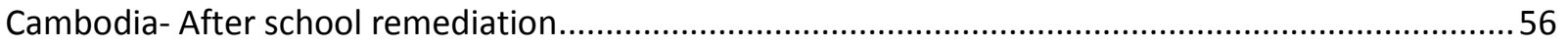

Cambodia - Child to Child Activities - peer tutoring ….................................................................... 56

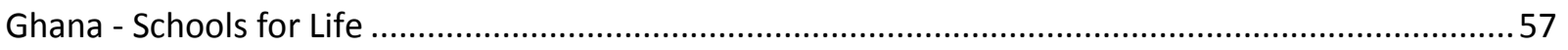

Senegal - PARI - Partenariat pour l'Amélioration des Rendements Internes à l'Ecole Elémentaire.......57

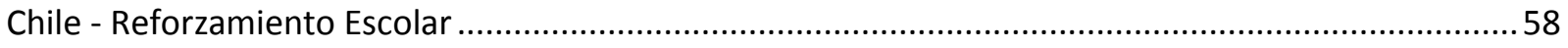

Annex VV. Definitions:

Annex XX. Sample of work plan for remedial instruction in a primary state school in the city of Campinas, Brazil (in Portuguese)

Annex YY. Links and Resources. 


\section{Executive summary}

Students from low income background often fall behind early on their education journey. Without adequate and timely support to address their learning needs they continue to perform poorly. Eventually the students lagging behind, will keep failing to learn the basic literacy and numeracy skills, and most likely will end up dropping out of school illiterate. The majority of Global Education Partnership (GPE) countries have acknowledged in their Education Sector Plans ${ }^{1}$ and Strategies the need to address the problem of low learning levels, and of students not going efficiently through the public education system, which has resulted in wastage of financial and human resources. Ideally interventions that aimed to improve learning of low performing students should be included in the framework of a country's educational policies in alignment with other institutional arrangements such as teacher training, curriculum, assessment, available pedagogic materials, instructional time, language of instruction (when applicable), among others. However, many of these countries are yet to draft policies that would specifically focus on helping low performers.

In this context, what can be done when students start to fall behind and continue to have problems to master the required curriculum? The default strategies in low income countries have been grade repetition, private tutoring, and automatic promotion. Learning one more time the same content in the same way usually does not lead to improved outcomes and repeaters most likely end up dropping out of school ${ }^{2}$. Private tutoring has also been widely used as remedial strategy and while it can be effective in improving academic achievement and reducing mainstream teacher's workload (Bray, 2009), it is only available to students whose families can afford it, leaving the poor further excluded ${ }^{3}$. Automatic promotion is prevalent in many low income countries, and while it allows students to move through more efficiently, it does not guarantee learning ${ }^{4}$. Automatic promotion may work only if implemented with

\footnotetext{
${ }^{1}$ http://www.educationfasttrack.org/partners/developing-countries/

${ }^{2}$ In sub-Saharan Africa alone, 10 million children drop out of primary school every year (UNESCO, 2010). Late school entry also contributes to low performance and eventual drop out. A study on late entrants in Mozambique (Wils, 2004) showed that these students have substantially higher drop-out rates than young entrants and may have, in addition, higher repetition rates. It is the case in Mozambique that students in first grade are probably older than reported by the schools.

${ }^{3}$ Rather than collectively address low education performance, private tutoring increases classroom disparities and in some countries it has been an incentive for teachers to engage their services for private lessons (Bray, 2009).

${ }^{4}$ Some countries have started to acknowledge the negative effects of automatic promotion. A commissioner from the Oyo State in Nigeria, has announced the ban of automatic promotion in the state's public schools due to mass failure of the state students in public examinations. He stressed that government at all levels should give priority to
} 
adequate academic support for students who were considered at risk to repeat the grade or drop out. Unfortunately these strategies have not been very successful, particularly for the most disadvantaged, and therefore there is an urgent need for low income countries to implement evidence based interventions that would efficiently promote learning for all of its students, and not just the privileged few.

Remedial education programs are defined here as specific educational interventions aimed at addressing learning needs of a targeted group of children who are lagging behind academically or not mastering specific competencies in the early grades. They can be an important element among the efforts to improve education outcomes of low performing students of different ages and in very diverse environments, particularly the most disadvantaged (World Development Report, 2007). Traditionally, children who have been excluded, who live in remote or conflicted affected areas, orphans and other vulnerable groups are most likely to need remedial education. Students receiving poor quality instruction, and who do not manage to follow the regular classroom can benefit greatly from remedial instruction before they lose interest in continuing to study and fail. ${ }^{5}$

Implementing extra academic support in already poor resourced school systems can be very challenging in terms of human and financial resources ${ }^{6}$, and for that reason remedial programs in low income countries are few and they have not been fully researched. However some programs do exist and it is important to know what they are and what we can learn from them. Baxter \& Bethke (2009) make a distinction between remedial and accelerated programs, where the former originates from assessing the core learning competencies and focuses on the mastery of those competencies such as the "Read India" remedial summer program (Banerji \&Walton, 2011). The accelerated programs provide the same content as the formal curriculum but at a faster pace, mostly targeting over aged students, out of school children or children leaving in remote areas with little access to primary education as in the case of students from

the acquisition of the foundations of primary education and that its standards should not be compromised (Ogunsola, O., 2012). Daily Independent, January 5 ${ }^{\text {th }}$, Lagos, Nigeria. Accessed April 10, 2012.

${ }^{5}$ In Canada, many aboriginal children have experienced several years of reading failure. And statistics show chronic school dropout among Aboriginal youth (Department of Indian Affairs and Northern Development, 2005) with many reporting that reading difficulties was a contributing factor for their decision to leave school (Hayward, Das, \& Janzen, 2007).

${ }^{6}$ The variation of information on costs of remedial education programs mirrors the diversity of such programs. Since remediation may be just a component of educational intervention or reform it is also difficult to isolate its specific costs. In Senegal the PARI afterschool programs implemented in the summer vacation costs about \$20 dollars per student (PARI Senegal, 2011). In Brazil, remedial education in the early grades implemented at school during the school year by regular teachers costs about $\$ 150$ dollars per student per year (Instituto Ayrton Senna, 2011). 
the Schools for Life ${ }^{7}$ in Ghana. The focus of this paper is on remedial types of programs aimed at improving reading in the early grades.

Governments and some NGOs in low income countries have established some form of remedial education programs to help students catch up with reading or math in the early grades, many starting as small pilots. It is not uncommon for remedial interventions, such as in the format of teacher training to improve the quality of early literacy instruction, to be delivered to entire classrooms or schools where baseline assessment results indicate very low levels of literacy for a majority of assessed students. Training teachers to teach the national curriculum with emphasis on reading (Save the Children, 2010), including scripted lesson plans, together with ongoing support to apply research based strategies to help low performers is one approach shown to be effective. However, it is often the case in low income contexts that not all teachers are able to reach all students due to large classrooms and short school days.

Some countries have introduced remedial programs that take place during the summer or after regular classes, conducted by teachers or others such as peer tutors, para teachers or even family members. Their intensity can vary from a couple of hours a week on a particular subject to daily instruction in a separate classroom for students needing to catch up with the curriculum. Para teachers and other assistants, usually community members, after receiving some training can provide the necessary extra attention to struggling students. Results from programs that use such approach have been encouraging. Early intervention can be particularly effective in improving reading skills (Vellutino \& Scanlon, 2001).

While it should acknowledged the diversity of the interventions in terms of intensity, duration and mode of delivery, and therefore the lack of comparability, a number of actions pointed out from program evaluations can shed some light on certain considerations that may lead to positive results when planning for such remediation types of programs. Experiences and lessons learned from remediation in developing countries can help to inform policymakers and stakeholders on what types of interventions may be feasible to implement under their education system's constraints.

Currently, it can be concluded that academic improvements from remedial support may help students to pass the grade or yield fast improvements, however such interventions by themselves may have not been sufficient to raise achievement at adequate levels. Remedial education programs will likely be most effective when included as part of a country's overall strategic plan to deliver quality education for all of its students. Overall, the renewed focus on

\footnotetext{
${ }^{7}$ School for Life is a nine-month education program for 8 to 15 year olds living in Ghana's rural Northern Region. The curriculum is comprised of local language literacy, numeracy, and general academics equivalent to three primary school grades in nine months (DeStefano, Moore, Balwanz, \& Hartwell, 2007).
} 
low performers, many times victims of teacher neglect and other social exclusion experiences, by the means of directing programs and resources to address learning gaps is already a huge step towards achieving learning for all.

\section{Introduction}

Over the last decades, great efforts have been made to increase school enrollment, or the "demand-side" of education. This alone has not necessarily resulted in improved educational outcomes in terms of learning and basic education completion. In fact, the rapid increase of enrollment in the primary grades in developing countries in the last decade, mainly in SubSaharan Africa, has posed new challenges to already overburdened schools. Hence, while a number of countries have significantly increased enrollment in the early grades of schooling, particularly for children from low-income and other disadvantaged backgrounds, achievement levels have remained generally low (UNESCO, 2011). Toward this background, remedial education programs try to strengthen the "supply side" of education, by offering additional opportunities to learn and thereby strengthening of education.

\section{What are the specific design features of remedial education programs?}

Remedial education programs consist of educational interventions aimed at addressing learning needs of a targeted group of children who are lagging behind academically or not mastering specific competencies, starting in the early grades. Remedial education can be implemented as a standalone program in or outside of school hours ${ }^{8}$, integrated in programs that are implemented as components of a more comprehensive educational program or project ${ }^{9}$; be a component within a country's curriculum guidelines and even of a country's education policy. One important feature of remedial education programs is determining the competencies that need improvement and the learning levels of program participants at the time of selection, during, and after the intervention. It has been argued that programs have to be explicit, systematic and focused to be effective: for example Houtveen \& van de Grift (2007) found that children who fail to learn how to read in the first grade as expected, can significantly improve reading and spelling from remediation that is explicit, systematic, and focused on both wordlevel skills and frequent opportunities for text-based reading.

\footnotetext{
8 Example of remedial education out of school hours are the Balsakhi program in India (Banerjee, Cole, Duflo, \& Linden 2006) or the PARI (Partenariat pour l'Amélioration des Rendements Internes à l'Ecole Elémentaire) summer program in Senegal (PARI Senegal, 2011).

${ }^{9}$ An example of remedial education as a component of a more comprehensive program would be the UNICEF country program for Belize, where strategies to improve the quality of primary education include mainstreaming remedial teaching by explicitly combining it with other efforts to strengthen bilingual and bicultural education and with strategies to engage parents in their children's learning so as to reduce school dropout and repetition (UNICEF, 2007).
} 


\section{How remedial programs differ from accelerated or complementary programs?}

Some aspects of remedial programs overlap with what sometimes has been defined as complementary models (DeStefano, Moore, Balwanz, \& Hartwell, 2007) or alternative education programs (Baxter \& Bethke, 2009) in terms of goals, target population, and effectiveness in improving learning outcomes and reaching the most underserved. Baxter \& Bethke (2009) make a distinction between remedial and accelerated programs, where the former originates from assessing the core learning competencies and focuses on the mastery of those competencies such as the "Read India" remedial summer program (Banerji \&Walton, 2011), and the accelerated programs provide the same content as the formal curriculum but at a faster pace, mostly targeting over aged students, out of school children or children leaving in remote areas with little access to primary education as in the case of students from the Schools for Life ${ }^{10}$ in Ghana.

How should these programs be implemented, and does it matter when remedial efforts start? It could be expected that, to be more effective, remedial interventions should start early on: for example, the sooner reading difficulties are addressed the faster reading outcomes will improve. However remedial interventions that address the problems of students early on may be more costly (as they may be less targeted to struggling students), but could be justified if they result in learning improvement from the lowest achievers, less repetition and drop-out rates, and an increase in the completion rates for basic education. Yet, evaluation results from the "Read India" or the Schools for Life (Ghana) programs indicate that remedial programs can be effective even when interventions occur later on, i.e., remedial programs that are not bound to the age-grade system can be effective in reducing the learning deficits found in a country's education system (Banerji \&Walton, 2011).

\section{Remediation to Meet Education Sector Strategies}

High repetition rates and school dropout, in addition to the great number of school age children out of school due to low performance and low quality of education, have driven countries to find strategies to improve educational outcomes in the format of alternative programs that go beyond regular instruction. As indicated in Table 1, strategic objectives range from including remedial support for students with learning difficulties, pedagogical support to implementation of accelerated programs, among others. They indicate a clear demand for remediation and other types of academic support to address learning gaps at all levels.

\footnotetext{
${ }^{10}$ School for Life is a nine-month education program for 8 to 15 year olds living in Ghana's rural Northern Region. The curriculum is comprised of local language literacy, numeracy, and general academics equivalent to three primary school grades in nine months (DeStefano, Moore, Balwanz, \& Hartwell, 2007).
} 
Table 1. Education Sector Plans and strategies of selected developing countries that include remediation on other academic support for low performing students ${ }^{11}$

\begin{tabular}{|c|c|c|c|}
\hline Country & $\begin{array}{l}\text { Main obstacles } \\
\text { and goals }\end{array}$ & $\begin{array}{l}\text { Programs for out of } \\
\text { school children }\end{array}$ & $\begin{array}{l}\text { Strategic objectives focusing on remediation and } \\
\text { other academic support }\end{array}$ \\
\hline Benin & & & $\begin{array}{l}\text { "Improve and implement pedagogical support to } \\
\text { schools" (Plan Decennal de Developpement du } \\
\text { Secteur de L'Educacion 2006-2015) }\end{array}$ \\
\hline \multicolumn{4}{|l|}{ Bhutan } \\
\hline Cambodia & & $\begin{array}{l}\text { Re-entry programs } \\
\text { for school drop outs }\end{array}$ & $\begin{array}{l}\text { Expansion of nonformal education for re-entry } \\
\text { programs in the formal school system }\end{array}$ \\
\hline Cameroon & $\begin{array}{l}\text { Address high } \\
\text { repetition and } \\
\text { improve internal } \\
\text { efficiency }\end{array}$ & & $\begin{array}{l}\text { Remediation and pedagogical assistance for learners } \\
\text { with difficulties (Education Sector Strategy 2006- } \\
\text { 2010. p.108-109) }\end{array}$ \\
\hline $\begin{array}{l}\text { Central } \\
\text { African } \\
\text { Republic }\end{array}$ & $\begin{array}{l}\text { To decrease } \\
\text { repetition rates }\end{array}$ & & $\begin{array}{l}\text { Implement remediation for teachers, provide } \\
\text { support for students with learning difficulties, } \\
\text { mostly girls (Education Strategy, p.80, p.82) }\end{array}$ \\
\hline $\begin{array}{l}\text { Côte } \\
\text { D'Ivoire }\end{array}$ & & & $\begin{array}{l}\text { Implement supporting courses, develop a school } \\
\text { monitoring system for school to implement } \\
\text { remediation for low achieving students (Education } \\
\text { Sector Plan 2010-2013, p.37) }\end{array}$ \\
\hline Djibouti & $\begin{array}{l}\text { High repetition; } \\
\text { drop out } \\
\text { without } \\
\text { necessary basic } \\
\text { skills }\end{array}$ & & $\begin{array}{l}\text { Need for an evaluation system to assess basic } \\
\text { learning skills and necessary remediation (Action } \\
\text { Plan Education Sector2006-2012; Country } \\
\text { Milestones 2010-2012, p. 45) }\end{array}$ \\
\hline Ethiopia & $\begin{array}{l}\text { High dropout } \\
\text { rates mainly in } \\
\text { Grade I }\end{array}$ & $\begin{array}{l}\text { Expand nonformal } \\
\text { education and } \\
\text { develop measures } \\
\text { to enroll out of } \\
\text { school children } \\
\text { specially girls } \\
\text { (Education Sector } \\
\text { development } \\
\text { plan.42) }\end{array}$ & $\begin{array}{l}\text { All school age children can learn and many of them } \\
\text { need some form of support in learning and active } \\
\text { participation. } \\
\text { Education leaders at all levels including school } \\
\text { managers and teachers have to be aware and be } \\
\text { able to support learners according to their needs } \\
\text { (Education Sector Development Plan, p.31) }\end{array}$ \\
\hline The Gambia & $\begin{array}{l}\text { Low } \\
\text { performance of } \\
\text { students } \\
\text { entering } \\
\text { secondary } \\
\text { education } \\
\text { High repetition }\end{array}$ & & $\begin{array}{l}\text { Remedial classes for students entering secondary } \\
\text { education to compensate for low quality of primary } \\
\text { schools (Education Sector Plan 2008-2011, p.29) }\end{array}$ \\
\hline
\end{tabular}

${ }^{11}$ Note: The Education Sector Plans and other related documents referred on this table can be found in the link for each partner country at the Global Partnership for Education (Former Fast Track Initiative) page:

http://www.globalpartnership.org/developing-countries 


\begin{tabular}{|c|c|c|c|}
\hline & rates & & \\
\hline Georgia & $\begin{array}{l}\text { Children } \\
\text { representative } \\
\text { of ethnic } \\
\text { minorities and } \\
\text { considered of } \\
\text { special needs }\end{array}$ & & $\begin{array}{l}\text { Schools prepare to address special education needs } \\
\text { (Consolidated Strategy Action Plan 2007-2011) }\end{array}$ \\
\hline Ghana & & & $\begin{array}{l}\text { Alternative primary education such as shepherd } \\
\text { schools (Education Sector Plan, 2004, p.10) }\end{array}$ \\
\hline $\begin{array}{l}\text { Guinea } \\
\text { Bissau }\end{array}$ & $\begin{array}{l}\text { Poor } \\
\text { attendance, late } \\
\text { entry high } \\
\text { repetition, child } \\
\text { labor }\end{array}$ & $\begin{array}{l}\text { Vulnerable groups } \\
\text { and excluded } \\
\text { children }\end{array}$ & $\begin{array}{l}\text { Strategy for excluded children, to increase education } \\
\text { demand; no mention of specific remedial education } \\
\text { (Three Year Plan for the Development of Education } \\
\text { 2011-2013) }\end{array}$ \\
\hline Guyana & $\begin{array}{l}\text { Rising repetition } \\
\text { and dropout } \\
\text { rates }\end{array}$ & & $\begin{array}{l}\text { Introduce new literacy methods based on } \\
\text { international practice (Ministry of Education } \\
\text { Strategic Plan 2003-2009) }\end{array}$ \\
\hline Honduras & $\begin{array}{l}\text { High repetition } \\
\text { and dropout } \\
\text { rates }\end{array}$ & & $\begin{array}{l}\text { Develop alternative programs for over aged children } \\
=10 \text { years old or older (Education Sector Plan 2002) }\end{array}$ \\
\hline Kenya & & $\begin{array}{l}\text { School age children } \\
\text { outside the schools } \\
\text { system }\end{array}$ & $\begin{array}{l}\text { Non formal education programs (Education Sector } \\
\text { Support Program 2005-2010) }\end{array}$ \\
\hline Lao PDR & $\begin{array}{l}\text { Reduce drop out } \\
\text { and repetition } \\
\text { rates }\end{array}$ & $\begin{array}{l}\text { Expand access to } \\
\text { equivalency and re- } \\
\text { entry programs for } \\
\text { school drop-outs } \\
\text { and unemployed } \\
\text { youth in both } \\
\text { urban and rural } \\
\text { areas }\end{array}$ & $\begin{array}{l}\text { Increased promotion rate from Grade } 1-9 \text { and } \\
\text { transition rate from Grade 5-6 through setting up } \\
\text { progressive promotion with remedial classes during } \\
\text { vacation time (Education Sector Development } \\
\text { Framework 2009-2015, p. 30) }\end{array}$ \\
\hline Lesotho & & & $\begin{array}{l}\text { "Provide opportunity for remedial lessons for slow } \\
\text { learners" (Education Sector Plan 2005-2015, p. 62) }\end{array}$ \\
\hline Liberia & & $\begin{array}{l}\text { Accelerated } \\
\text { programs through } \\
\text { UNICEF to complete } \\
\text { primary education } \\
\text { for children normal } \\
\text { school age by the } \\
\text { end of the conflict }\end{array}$ & $\begin{array}{l}\text { "Clear the back log of new entrants to Grade } 1 \text { and } \\
\text { Grade } 3 \text { above } 11 \text { years old by registering them in an } \\
\text { compressed primary school program" (Education } \\
\text { Sector Plan, 2010, p. 70) }\end{array}$ \\
\hline Malawi & $\begin{array}{l}\text { High repetition } \\
\text { High proportion } \\
\text { of orphans and } \\
\text { other vulnerable } \\
\text { children }\end{array}$ & $\begin{array}{l}\text { Basic education } \\
\text { provisions for out of } \\
\text { school youth (p.27) }\end{array}$ & $\begin{array}{l}\text { Use of existing education infrastructure to } \\
\text { implement complementary basic education, design } \\
\text { accelerated programs } \\
\text { (Appraisal of the Government of Malawi's' } \\
\text { Education Sector Plan) }\end{array}$ \\
\hline Mali & $\begin{array}{l}\text { High repetition } \\
\text { rates }\end{array}$ & & $\begin{array}{l}\text { Teachers will be trained to carry out formative } \\
\text { evaluation and in remediation to improve the } \\
\text { performance of students with learning difficulties } \\
\text { (Education Sector Plan, Descripcion de la Second } \\
\text { Phase 2006-2008) }\end{array}$ \\
\hline Nepal & Improve quality & & Implementation of continuous assessment and a \\
\hline
\end{tabular}




\begin{tabular}{|c|c|c|c|}
\hline & and relevance & & $\begin{array}{l}\text { remedial support system (p.20); introduction of a } \\
\text { Continuous Assessment System (CAS) with rigorous } \\
\text { remedial support programs (p.22); provide remedial } \\
\text { support to those students lagging behind (p.30) } \\
\text { (School Sector Reform Plan, 2009-2015) }\end{array}$ \\
\hline $\begin{array}{l}\text { Papua New } \\
\text { Guinea }\end{array}$ & & $\begin{array}{l}\text { Recommends a } \\
\text { study on costs of } \\
\text { accelerated } \\
\text { programs for over } \\
\text { aged children (p.48) }\end{array}$ & $\begin{array}{l}\text { "In case the teacher is not able to provide sufficient } \\
\text { support for these "weaker pupils", remedial } \\
\text { teaching by other teachers or parents will be } \\
\text { considered to be addressed under the School } \\
\text { Development Plan" (Universal Basic Education Plan } \\
\text { 2010-2019, p. 35) }\end{array}$ \\
\hline Rwanda & $\begin{array}{l}\text { Lack of a } \\
\text { national system } \\
\text { to monitor } \\
\text { acquisition of } \\
\text { literacy and } \\
\text { numeracy skills }\end{array}$ & & $\begin{array}{l}\text { "Schools do not have remedial programs in place" } \\
\text { (Education Sector Strategy Plan, 2010-2015, p. 23) }\end{array}$ \\
\hline Senegal & & & $\begin{array}{l}\text { "integrate to the school plan remediation strategies } \\
\text { of academic support to students with learning } \\
\text { difficulties" (p.74); linguistic remediation for French } \\
\text { (p. 87) (Education Sector Plan 2008) }\end{array}$ \\
\hline Togo & $\begin{array}{l}\text { Reduce } \\
\text { repetition in } \\
\text { primary school }\end{array}$ & & $\begin{array}{l}\text { "Improve teaching and learning including a good } \\
\text { evaluation tool to detect learning difficulties and } \\
\text { pertinent remediation"(p.30); apply a differentiated } \\
\text { pedagogy and remediation to support students with } \\
\text { learning difficulties (p. 63) (Education Sector Plan } \\
\text { 2010-2020) }\end{array}$ \\
\hline Uganda & & & $\begin{array}{l}\text { "Teachers need to continuously assess the progress } \\
\text { of pupils and provide remedial help when pupils fall } \\
\text { behind" (p.53); schools will be helped to organize } \\
\text { their resources to provide remedial } \\
\text { work"(p.54)(Updated Education Sector Strategy } \\
2010-2015)\end{array}$ \\
\hline Vietnam & & $\begin{array}{l}\text { Non-formal } \\
\text { education } \\
\text { opportunity for out } \\
\text { of school youth }\end{array}$ & (National Education for All (EFA) Country Plan) \\
\hline
\end{tabular}

The need to remediate learning gaps at all levels of education is clear and urgent. Rather than being comprehensive, this review focuses on some key design and implementation issues, so as to spur further interest in remedial education as an effective tool for accelerating learning for low-achieving students, mainly in the early grades. It is guided by the following questions:

- What are key issues for the design and implementation of remedial programs?

- How effective have remedial education programs been?

- How remedial education interventions may be an important component to improve education outcomes of the most disadvantaged students? 
Information on remedial education this paper comes from peer-reviewed studies, existing literature reviews in remedial education focusing on reading at the primary level or early grades, and other related publications, mainly in English. ${ }^{12}$ The paper concludes with summarized country examples of remedial programs. Annex $Y Y$ has a list of resources to further explore the remedial programs referred in this paper. Annex $Q Q$ describes potential linkages between remedial education programs and education strategies of multilateral and bilateral agencies. Annex RR includes selected remedial education approaches and research in the United States. Annex SS also offers more detailed descriptions of various programs mentioned in this study, such as the PARI in Senegal and Ler e Aprender in Brazil. ${ }^{13}$

\section{Designing Remedial Education Programs}

Remedial education programs share many features with complementary and alternative education models. A key feature for all these is the goal to provide alternative or additional means of reaching underserved populations, provide access to learning opportunities, at some level reduce inequity, and produce significant learning outcomes - that is, children who learn to read and write with fluency or children who may be able to show adequate performance and pass to the next grade.

As remediation can take so many forms in such a variety of settings, it is important to focus on its most important aspects in order to make the best decisions for interventions to be most effective. Identifying students with learning difficulties and low achievers, defining the competencies and other learning needs of the target learners that need to be addressed, how and by whom the instruction will be delivered, and how progress will be measured and monitored are key issues that will be discussed in the following sections.

\section{a. Defining low performing students}

Students needing remedial education may be identified by their teachers, informally selected among students with low test scores, or may be part of a specific group selected for a remedial intervention. Teachers may receive training on how to better identify student's learning needs. To receive remedial instruction in the ESCUP project in Cambodia, students considered slow

\footnotetext{
${ }^{12}$ Information of remedial education projects or interventions was also compiled from project evaluations, reports, as well as from reviews of selected USAID and other donor funded programs, NGO's, and international organizations' projects. This paper also benefited from feedback and suggestions of World Bank country officers and education specialists.

${ }^{13}$ Due to the considerable variation of the design and implementation of remedial education, this review will not be discussing programs costs. However, when available total costs of program or cost per student will be cited for the programs listed in the Annexes.
} 
learners are the ones who score below average on the semester exams (AIR \& World Education, Inc., 2008). It is not uncommon for remedial interventions, such as in the format of teacher training to improve the quality of early literacy instruction, to be delivered to entire classrooms or schools where baseline assessment results indicate very low levels of literacy for a majority of assessed students. In selected schools in Malawi, 95\% of tested second grade students scored zero in fluency, accuracy and comprehension before the implementation of Literacy Boost program by Save the Children (Save the Children, 2010).

\section{b. Defining remedial intervention goals based on learning needs}

Remedial education interventions aim to address the learning needs of students or others who have not being able to master the necessary skills to be able to attain a basic education. The goals expected outcomes of such interventions will be based on what those learning needs are. Below are some examples of remedial interventions' goals together with selected programs designed to meet them.

\section{Improving reading and math skills}

Early fluency in reading is fundamental to success in school (Abadzi, 2006), laying a strong and necessary foundation for future academic achievement (Scarborough, 2001). It is widely expected that children should be able to be fluent readers by the end of first grade. Since automatic readers do not lapse back into illiteracy, children who drop out but who are able to read fluently should improve comprehension and skills as they go to work (Abadzi, 2010). Existing research emphasizes that learning to read at an early age (Scarborough, 2001) as well as the development of concrete early math skills (Duncan, Claessens, Huston, et al. 2007) lay a strong foundation for future academic success. Therefore learning gaps need to be detected and addressed as early as possible while they can be remediated more effectively.

\section{Providing an alternative to grade repetition and avoiding drop out}

Children repeat grades who fail to achieve the expected competencies within the model of being grouped by grade defined by curriculum content and cognitive demand independent of age and capability, and ordering progression sequentially from grade to grade (Lewin, 2007). Well targeted and well implemented remedial interventions can give an opportunity for low performing students to catch up with their peers and possibly avoid grade repetition. To prevent grade repetition, the PARI program in Senegal selects at risk students from Grade 1 and from Grade 5 and provides summer remedial programs that deliver academic support so students at risk of repeating a grade can have a chance to master the content necessary to progress to the next grade (PARI Senegal, 2011).

\section{c. Defining indicators of expected outcomes}

Indicators of expected outcomes of the remedial interventions will be planned based on the learner's level and educational needs. They can be as broad as passing the grade or as specific 
as acquiring reading fluency. In terms of improvement of access, the PARI program in Senegal expects that: at least $80 \%$ of selected students should be enrolled in the support program in $\mathrm{Cl}$ (first grade) with $50 \%$ being girls; at least $80 \%$ of selected students in $\mathrm{CM} 1$ ( $5^{\text {th }}$ grade) should be enrolled in the program with $50 \%$ being girls. As of expected performance, $100 \%$ of students from which at least $50 \%$ being girls should pass the post test. According to the latest report (World Bank, 2010), while results of the posttest are not yet available, anecdotal evidence from the PARI program actors indicated important improvements as far as the students' achievement level and in terms of reducing repetition rates.

Similarly, the Pratham's summer camps in India which targeted children 6 to 14 years old expected children to increase learning by one level or more specifically:

- Children who are beginners or can read letters should be able to read words.

- Children who can read words and paragraphs should be able to read stories.

- Children who are beginners and can recognize numbers only up to 9 should be able to recognize numbers up to 100 and solve simple addition/subtraction sums and should know multiplication tables up to 5.

- Children who can do addition and subtraction should be able to recognize numbers up to 100,000 , know tables up to 10 and solve word arithmetic sums up to division (Pratham, 2008).

In Chile, the remedial program for children living in extreme poverty implemented by the nonprofit Un Techo para Chile expects that children will improve their Spanish and math scores as well as study and social skills and continue to be attending school in the following school year (Contreras \& Herrera, 2005). Evaluations from the Literacy Boost program implemented in Malawi and Mozambique aimed at improving children's core reading skills have used even more specific indicators to measure improvement of students in Grades 2 and 4 such as \% of letters identified, \% of words read correctly, and words read correctly per minute. Tests also included 16 numeracy questions (Save the Children, 2011).

\section{Prepare participants for reintegration in the regular classroom or to move to another level}

In addition to improve learning for low performing students, outcomes of remedial education programs may also include the ability of participants to go to next level of their educational journey as for example being able to return to the appropriate grade, complete basic education or successfully re-enter the formal school system in the case of out-of-school students. Pull out programs for students with reading difficulties such as Reading for Success in the US are designed to be related to the general education curriculum, with an actualized plan for returning the student to regular education (Idol, 2010). Other countries have implemented similar models to address problems of inefficiency in the school system. 


\section{Remedial Education Programs in Brazil to Improve School System Efficiency}

In 1997 the Brazilian government established in its National Education Plan that public schools could form separate classes to address the large number of low performing students whose age were not on par with their grade due to grade repetition or late entry at school. The program called Acelera Brasil which may be considered the largest remedial program implemented in public schools in a systematic way. The goal was to have students master in a shorter time the expected content to be able to reenter in the grade appropriate for their age. As the program started to be implemented through the states, initial evaluations of achievement in the early grades showed that about 30 to $40 \%$ students would keep repeating grades because they did not learn how to read. Therefore, while the curriculum of this program includes math and other subjects, the main focus is on reading. Presently the program has separate classes for illiterate students called Se Liga. Once students become literate, they join the other accelerated classes until they can finally be able to re-enter regular classes in the appropriate grade for their age.

These are some reported results of Acelera Brasil in various states it has been implemented:

- Within a period of five years $52 \%$ of participating students in the State of Paraíba were able to pass more than one grade and therefore adjusting the student flow.

- In the State of Pernambuco, the dropout rate of participant students (3.2\%) is lower than State average of $14.8 \%$.

In the State of Tocantins, $99 \%$ of graduates from the Acelera Brasil were promoted to the next grade (Instituto Ayrton Senna, 2011). While these are indicators that the program can improve the efficiency of the school system, there are few studies in Brazil linking participation in these remedial programs and students' performance in standardized tests or other measures of learning achievement. A study with a sample of 9,000 6th graders attending 90 public state schools in Campinas, Brazil in 2007 found that students who have attended acceleration classes or other remedial support at school were more likely to present significantly lower test scores in math and Portuguese when compared to their peers as measured by the Saresp test (Schwartz, 2011). These may indicate that the academic improvements from the remedial support may help students to pass the grade but have not been sufficient to raise achievement at adequate levels, therefore more studies are needed on the effects of participation on remedial programs and students' expected levels of academic performance.

\section{Implementing and Delivering Remedial Programs}

Once a target group has been identified, program objectives and expected outcomes have been defined; the key issue for increasing the effectiveness of remedial programs is to choose the delivery mode or modes that will meet the stated objectives. This section will describe and cite studies and findings of remedial education programs that used each a variety of instructional 
delivery modes. Choosing a delivery mode will heavily depend on the available resources since tutoring for example, can be more costly than teaching in small groups. Benefits and examples of delivery by tutoring, small groups, separate classrooms and other arrangements will also be discussed in this session.

\section{a. Modes of Implementation and Delivery}

\section{Small groups tutoring}

Small group reading interventions for example, can be effective for students who are not being able to make progress in the regular classroom reading instruction. In low income countries where the public education system faces many challenges to provide quality education, it may be very costly in terms of financial and human resources to have separate small classes to deliver more intensive instruction for students lagging behind.

In the United States, when progress-monitoring assessments indicate that students are not making enough progress with quality classroom reading instruction alone, schools can provide extra small-group reading intervention to ensure that all children learn to read in the early grades (see Denton \& Mathes, 2003; Fletcher, Denton, Fuchs, \& Vaughn, 2005; Vaughn, Wanzek, Woodruff, \& Linan-Thompson, 2007)Research evidence points out that the most effective format to improve reading is one teacher for three students (Vaughn, S., LinanThompson, S., Kouzekanani, K., Bryant, D.P., Dickson, S., \& Blozis, S.A., 2003; Elbaum, Vaughn, Hughes, \& Moody, 2000). Clearly this is not feasible in low income country contexts, however there are remedial programs that provide remedial support for larger groups with some positive results. The Balsakhi program in India is an affordable way that enables low income children from grades 3 and 4 who were identified as low achievers to benefit from tutoring programs. The tutors were women selected from the community and were paid very low fees by Pratham, the implementing NGO. Children are taken out of the classroom and the tutors work in groups of 15-20 low performing learners for two hours each day (the school day last about 4 hours) (Banerjee, Cole, Duflo, \& Linden, 2006).

\section{Separate classrooms for low performing students}

In some states in Brazil, public schools can form a separate classroom to support low achieving students in the first five years of schooling if there are at least fifteen students identified as needing remediation by their teachers. Students would return to the regular classes once they master the required skills (Secretaria Municipal de Educação de São Paulo, 2006).

\section{Grouping students by ability}

There is mixed evidence on the effectiveness of interventions that group students by ability, what may be classified as "tracking". In some contexts it may improve the quality of instruction for all students. Evaluation of the Extra Teacher program in Kenya designed to allow schools to 
add an additional section in the first grade benefited lower-achieving pupils indirectly by allowing teachers to teach at a level more appropriate to them (Duflo, Duplas \& Kremer, 2009. Program evaluation results showed students in classes grouped by ability performed better in the post test when compared to students who were in extra Grade 1 class with randomly assigned students, and concluded that positive effects for low achieving students were due mainly because students received a more tailored instruction to their needs under tracking which outweighed the reduction on peer quality.

Notwithstanding, in some cases tracking can have detrimental effects for low achievers if it results in discrimination and further exclusion of disadvantaged groups. Some argue that low achieving students may feel penalized and not be motivated to learn (Placco, de André, \& de Almeida, 1999). Students from "acceleration classes" in Brazil reported experiencing difficulties at the conclusion of the program and re-integration into the regular classrooms where they did not receive the same attention as they did in the acceleration classes, particularly in terms of building their self-esteem. At the same time, teachers in the regular classrooms had not been prepared in ways to best integrated students returning from acceleration classes (Placco, de André \& de Almeida, 1999). Qualitative evidence from Zimbabwe also supported this conclusion pointing out to teacher's discriminatory attitudes towards the low achieving class (Chisaka, 2002).

\section{Volunteer Tutoring}

Volunteer reading tutoring programs may be an affordable way for low income children to have access to this type of delivery. In the United States, Ritter, Denny, Albin, Barnett, and Blankenship (2006) reviewed 21 articles or reports based on the data from 1,676 study participants in 28 studies that assessed volunteer tutoring programs. They reviewed randomized only field trials published from January 1985 to August 2005 which yielded academic impacts. The programs were aimed at students in grades $\mathrm{K}-8$, and only used where adult, non-professional (volunteer) tutors. Results from this review showed that these programs can positively influence language and reading outcomes of elementary school students with an average effect size of $.30^{14}$.

Training for tutors, assessment-based instruction, structured reading sessions, and use of an on-site coordinator have been described as essential components of a tutoring program (Invernizzi, 2001). 


\section{Peer Tutoring}

Peer tutoring may also be an affordable option that can benefit all involved. Those activities where children work together in a learning task may help students to develop their sense of self-esteem and responsibility being active participants on their peer's learning. In the ESCUP project in Cambodia students helped their peers to learn, practice or review an academic skill that the class teacher has planned. For example, grade 5 and 6 teachers teach their students on how to help younger children to read and write (3 hours), so in their free time these students will help grades 1 and 2 students under the teacher's supervision. This support can also be giving in homework clubs where older students their peers to learn, practice or review an academic skill that has been assigned by the teacher as homework and in the case of Cambodia example it covered Khmer language and math (AIR \& World Education Inc., 2008).

\section{One-to One Tutoring}

Clearly private tutoring has been the default approach to deliver remedial instruction, particularly in high income countries where it may be affordable. Programs that provide one-toone, phonetic tutoring to students who continue to experience reading difficulties can result in positive effects (Slavin et al, 2010) and improve reading performance (Slavin et al., 2009). Oneto-one instruction can be very costly for low income students whose families have already high opportunity costs of keeping their children in school. Low income and disadvantaged students who are struggling academically can only rely on support that does not incur any furthers costs. Public school systems in low income countries also have scarce resources to implement programs outside the regular classroom delivery.

It is important to acknowledge that private tutoring, meaning instruction that is delivered for a profit, has become a thriving business in developing countries and it can contribute to the increase of social inequalities (Bray, 2007). One of the major costs in Bangladesh private tutoring is a phenomenon that is perpetuating inequality in education since children whose families cannot afford private tutors to prepare them for exams, they will likely have low performance (Hossain \& Zeitlyn, 2010).

\section{Computer Assisted Interventions (CAI)}

There is some evidence that Computer Assisted Interventions can also be one tool to address low performance. A computer assisted learning program was implemented by Pratham in the city of Vadodara in India targeting all children, but adapted to each child's current level of achievement attending grade 4.They received two hours of shared computer time per week, during which they play games that involved solving math problems whose level of difficulty responded to their ability to solve them. An evaluation of such intervention showed that the computer-assisted learning increased math scores by 0.35 standard deviations the first year, and 0.47 the second year, and was equally effective for all students. One year after the ends of the program, students at all levels of aptitude perform better in math (0.1 SD) if they were in 
schools where the computer-assisted math learning program was implemented (Banerjee, Cole, Duflo \& Linden, 2006).

Anecdotal evidence from a CAI type of program implemented in the public municipal schools of the city of Campinas in Brazil for grades 1 to 5 indicated that low performing students can improve their learning after being tutored by older peers on open source educational programs at their school computer labs. Those peer tutors are students who have been previously trained .They also help teachers to feel more comfortable and proficient in using the computer labs for instruction. As a result teachers started to use the lab as a means to give remedial support to low performing students (Fernandes \& Peluci, 2011).

\section{b. Settings for delivering remedial programs}

Remedial education, like other interventions that provide academic support, can be delivered in a variety of settings ${ }^{15}$ and they are not limited to just poor resourced environments. This session lists examples of remedial programs implemented in relation to curricular contexts that can be described as fully integrated into the curriculum (curricular) carried out within the schools outside the formal curriculum (co-curricular), or outside the school (extra-curricular) (Chabbott, 2006, p. 5).

\section{Remedial Education during school hours - curricular}

The literature in remedial education indicates that remediation is most effective as a complement to teachers' existing techniques rather than as a pure substitute. There is evidence in low income countries that remedial education implemented at school can have significant effects particularly for low performers.

Even with the best quality regular instruction as in the case of high income settings, still there will be some students with reading difficulties in the early grades. Direct Instruction is an example of a teaching methodology that was first implemented and evaluated in the United Sates and later tested in low income countries such as South Africa and Liberia. Research findings showed that that students in treatment classrooms had significantly improved their reading scores (DIBELS) when compared to students in the control classroom (Stockard, 2010).

In some low income countries the formal school system has planned for remedial activities at school. The basic education curriculum in Mali allocates $25 \%$ of weekly time for remedial activities which can be delivered during school hours or by the means of projects. Similarly, Botswana's curriculum expects 315 to 405 minutes per week to be dedicated to such activities from grades 1 to 4 of primary school (Georgescu, Stabback, Jahn, Ag-Muphtah, \& de Castro, 2008).

\footnotetext{
${ }^{15}$ This session draws on Chabbott's (2006) contexts of administration of reading interventions.
} 
In Brazil, State and Municipals Secretariats of Education have established curricular projects in the public school system that take place inside and outside the regular classroom to address the low levels of achievement in math and to prevent grade repetition focusing on the early grades. To focus on students' achieving reading and writing skills by the end of the first year of school, each Grade 1 classroom is assigned a university student enrolled in an education program to help the teacher with literacy activities. This project, called Toda Força (All the Power) been implemented through a partnership with participating universities and the students majoring in Education receive and stipend to participate in the program. For the students in last year of low primary education ${ }^{16}$. In the project Ler e Escrever (Reading and Writing), struggling students identified by their teachers and receive thirty hours per week of remedial instruction. In the following grades, the project Ler e Escrever is supposed to expand to all subject areas of the curriculum where teachers are trained to continue to work on reading comprehension and writing skills (Secretaria Municipal de Educação de São Paulo, 2006).

\section{ESCUP Cambodia teachers were trained to apply remedial interventions in the regular classroom}

"Training on remedial support to slow learners: A two-day teacher training workshop for remedial teachers" took place in four different locations in Kampong Cham and Kratie in February. A total of 101 primary teachers (68 female) participated in the trainings. The training sessions were conducted by IBEC project staff members with co-facilitation by experienced remedial teachers, trained in previous projects such as ESCUP and Schools for Life. The purpose of this training is to help teachers to prepare for the provision of remedial activities for children with special learning needs who are at risk of repeating or dropping out. Under this intervention, students at risk are identified at the end of the first semester, based on their Term 1 average scores. Remedial classes that are primarily village-based (to avoid the stigma of remediation) are offered to these students from the beginning of the second semester.

The trainings focused on the principles of teaching slow learners, factors that can hinder children's learning, teaching techniques for Khmer language and Mathematics, student task work analysis as a way to identify an appropriate response to the student's specific problems, and guidelines in identifying children with special learning needs. The training equipped participating teachers with better understanding of why some students face difficulties in learning and simple, effective tools to help them perform better. In all, 3,108 children are receiving remedial assistance at both primary and secondary school level. At least $80 \%$ of children remediated in Year 1 are promoted (World Education, 2010).

\footnotetext{
${ }^{16}$ The last year of low primary education in Brazil will be the $5^{\text {th }}$ grade since one more year was added to compulsory education with students starting primary school at six years of age instead of seven.
} 
Evaluation of the SMRS (Systematic Method for Reading Success) pilots which supplements a literacy program with a 30-45 minute addition to the regular curriculum carried out in Niger and Mali indicated that the program can be easily implemented alongside the school curricula with minimal disruptions because it lasts for four- to five-month period at the beginning of the school year. Results also showed that the SMRS could effectively put into place the necessary building blocks for reading acquisition over a relative short period, even shorter than what was observed government managed primary schools (Mitton, 2008).

\section{Remedial Education after school hours - co-curricular and extra-curricular}

There is also evidence that learning gaps in early grades can be addressed outside school and result in improvements in learning for students lagging behind. Home based remediation in Cambodia takes place in the home of students who scored below average on the semester exams. Teachers go to the student's home after school and provide support on the areas students classified as slow learners have most difficulties (AIR \& World Education Inc., 2008).

The Pratham's Shishuvachan curriculum in India was implemented in three different settings aimed to improve literacy skills. Researchers wanted to find where the intervention could be most effective. Evaluation results showed that the program was effective on average and improved literacy skills for all students when implemented in and outside public schools. However scores were significantly higher for the out-of-school time version which increased test scores by 0.24 standard deviations beyond the 0.26 standard deviation effect of the within school model. The evidence indicated that Shishuvachan was most effective when implemented as a complement to school curricula (He, Linden \& MacLeod 2009).

\section{Remedial Education as a summer program}

Evidence of significant improvement of programs implemented outside the classroom may explain the effectiveness of programs implemented during the summer vacation, another mode of delivery that is more effective when evaluating the same intervention implemented in different settings. Similar to the Pratham's Shishuvachan (He, Linden \& MacLeod 2009), remedial education provided in the format of a summer program, as implemented in Senegal for example, have helped thousands of children to improve their reading and math skills.

In Senegal the government implemented educational policies in 2010-2011 in order to reduce drop-out rates and improve primary completion rates. Aiming at improving quality and efficiency of the school system, one of the measures was the delivery of two-month remedial summer courses, the PARI (Partenariat pour l'Amélioration des Rendements Internes à l'Ecole Elémentaire) program aimed to improve reading and math, targeted at underperforming students in Grades 1 and 5 from schools with high repetition and drop-out rates. Post test results in French and math showed that from the 7,510 participant students in Grade 1, 5,450 were successful (76.62\%) from which 3,134 were girls (57.50\%). Some regions did better than 
others. As for Grade 5, 81.62\% of participant students were successful according to the post test measures (PARI Senegal, 2011).

In a larger scale, READ India implemented as summer program has reached thousands of children. In Bihar over 12,000 children, in 158 villages, and 264 government schools participated. The program targeted children in Grades 3, 4 and 5 who were not yet reading or doing arithmetic at Grade 2 level. Teachers were paid for an extra month's work to give remedial education and were supported by school-based unpaid village volunteers. $A$ randomized controlled evaluation of the program compared learning outcomes for different interventions with the control group. Read India implemented during summer vacation showed significant impacts in Hindi and math. Implementation of "Read India" during regular school hours had no significant effects. The study concluded that positive impacts were due to "grouping children in homogenous groups by ability level and conducting classroom activities designed for each group using appropriate teaching-learning materials" (Banerji \& Walton, 2011, p. 4).

\section{Remedial Centers}

Remedial Teaching centers have been implemented as a mode of delivery that supports students outside school. They enroll students who are or have been out of the formal education system and may be considered remedial in nature since returning students may start studying again at different levels based on their previous experiences in the formal school system, if any. In the Democratic Republic of Congo where almost half of school age children are excluded from the educational system or drop out early because of the costs of schooling and as a result are an easy target by armed groups, UNICEF in partnership with the government and NGOs, have provided support to students in remedial teaching centers where students are taught by primary school teachers who use the same textbooks and teaching materials from the formal school. The program in the remedial centers has reached thousands of children only after a couple of years of implementation. To enroll in the remedial centers, children had to be out of school in the last two years (UNICEF, 2010).

\section{c. Who should deliver remedial education instruction?}

Remedial education has been delivered by several education professionals as well as by members of the community and even by student peers. All of them have in some way been able to improve learning outcomes. Ideally, teachers should be trained to have the best tools to address the learning needs of all students. However there is a shortage of qualified teachers in low income countries and the demand is rapidly increasing. Another 1.9 million teachers will be needed by 2015 to achieve universal primary education, more than half of them in sub-Saharan Africa (UNESCO, 2010). In addition to needing more teachers, appropriate training with research based effective methodology is critical for effective instructional delivery. In high- 
poverty communities with shortages of teachers, allocating scarce qualified teachers to small numbers of children may be hard to justify. For those reasons, many schools have long used paraprofessionals or volunteers as tutors, usually with materials specifically designed for this purpose. Ritter et al. (2009) and Wasik (1997) reviewed research on volunteer tutoring programs, and both reported substantial positive effects.

\section{Teachers}

Teachers who receive quality professional development may be able to be more effective with low achievers. In the US six remedial reading teachers in a large, rural school district participated in a form of professional development called Teaching as Intentional Learning focused on formative assessment. Teacher's feedback was positive and they felt they grew professionally. In Grade 1, at-risk students assigned to these project teachers had increased reading readiness scores on one measure (DIBELS ) compared with at-risk students assigned to non-project teachers (Brookhart, Moss, \& Long, 2010).

Training teachers to be able to identify low performing students and provide the tools to address low achievement can yield important learning gains particularly on low income countries. The EGRA plus intervention in Liberia, an adapted form of EGRA to support teachers in monitoring education quality in its schools based on Early Grade Reading Assessment (EGRA), after only 4 months of implementation showed significant improvements for students in Grades 2 and Grade 3: participants children increased letter naming fluency by 21.0 letters per minute, phonemic awareness cores by $17.7 \%$, familiar word fluency by 15.7 words per minute, unfamiliar word fluency by 12.8 words per minute, oral reading fluency by 24.3 words per minute on connected text, and reading comprehension by $30.2 \%$.

In Cambodia, teacher education activities included support for remedial activities at both primary and secondary school level (World Education, 2010). The Local Language Initial Literacy (LLIL) in Ghana hires supplementary language teachers to teach literacy in local languages in Grade 1 and Grade 3 of primary school. Teacher training lasts for about three weeks each year and additional in-service training is offered throughout the year (DeStefano, Moore, Balwanz, \& Hartwell, 2007). 


\begin{abstract}
Remedial Activities in the Classroom
Changing the traditional pedagogy in the classroom and tailored instruction to meet the learning needs of low performing students may also involve teacher training activities where teachers reflect on their own practice and are more proactive to help those students. Teachers need to be trained to have the appropriate tools to find the reasons for low achievement as well as to be able to address learning gaps more effectively. These activities may include:

-teach the lessons again and provide additional teaching on parts of lessons that students have yet to understand;

- explain more;

- putting the slower students at the front of the class;

- work directly with the students not learning well in a small group;

- let weaker students work in a mixed group with other children who understand ;

- organize a remedial class;

- talk to parents about their children coming to school regularly (p.47)

Source: Ministry of Education, Youth and Sports (2007). Effective Teaching and Learning Facilitator's Manual. Cambodia. Retrieved on January 20, 2012 from http://www.equip123.net/equip1/escup/ActivityMenu/docs/et/Training eng.pdf
\end{abstract}

\title{
Community members, volunteers
}

Research on volunteer tutoring programs in the United States reported substantial positive effects (Ritter et al. ,2009; Wasik 1997). Paraprofessionals and volunteer instructors can positively influence language and reading outcomes for students (Slavin, 2009).

A review of alternative approaches to educational delivery in developing countries showed that motivated young adults, often with little formal qualifications, can serve-and serve well-as teachers when provided with ongoing professional training and support. All the programs studied had networks of well trained teachers who made visits once a month to the program schools. This support comes from decentralized systems that rely on local partners and nongovernmental intermediaries, providing effective ongoing services where ministry programs of in-service training and school supervision seldom succeed (DeStefano, Moore, Balwanz, \& Hartwell, 2007). 
Nonprofit organizations such as Un Techo para Chile (A Roof for Chile) recruits and trains volunteers, mostly university students who are interested in working with children, to teach remedial sessions in math and Spanish twice a week to children attending basic education living in areas of extreme poverty. A randomized evaluation of the program show significant improvement in scores for participants compared to eligible children not enrolled in the program (Contreras \&Herrera, 2005).

Pratham, a NGO that has been implementing large scale remedial education programs in India, has employed community volunteers as instructors in the remedial programs they implement. Volunteers earn less than regular teachers and experience from the Balsakhi remedial tutoring program showed that they foster a non-threatening learning environment, the tutor, called a balsakhi, or "child's friend," was typically a young woman hired from the local community and has completed at least secondary education (Banerjee, Cole, Duflo \& Linden, 2006).

\section{Family members}

Because of school closures and lack of access by thousands of students in the West Bank and Gaza, a UNICEF program funded by the Canadian International Development Agency (CIDA) has trained thousands of teachers and parents to help students study on their own or at home with remedial worksheets. Since its beginning in 2000, more than three quarters of a million students throughout the West Bank and Gaza have been using remedial worksheets covering core subjects like mathematics, science, English and Arabic. Some children have been using the worksheets at home for as long as three years (Ceraldi, 2006).

\section{d. What types of training for teachers and school administrators are needed for effective delivery of remedial education?}

There is scant information in terms of the content included in the training of teachers, volunteer, facilitators or other instructors, how long they should receive training and if what is learned has translated into practice. As for content, training of instructors who will help low achievers has to be designed in a way within the reach of the instructors' ability to understand the material so they can implement what they have learned in their training. This needs to be taken into account particularly in low income contexts where many facilitators or even teachers for example have only completed secondary education or less. The content of remedial education training has to include the most effective ways to improve reading outcomes and address illiteracy. Teachers also need to know how students' progress can be measured and tracked. However, in reality, even teachers with a higher education degree may not have been trained on how to assess students learning levels and use results to improve instruction for all students. 


\section{Applying the Diagnostic Teaching Approach}

The International Reading Association (IRA) has been using the Diagnostic Teaching Approach to train teachers and facilitators in their literacy programs and other basic education projects. At the end of the training, participants are expected to:

- identify the major components of the literacy process;

- explain the relationship between assessment and instruction;

- identify the main the processes for constructing meaning from print;

- identify and use diverse techniques for monitoring students' ability to use the main strategies for constructing meaning from print; and

- provide evidence of having adapted and applied techniques of the diagnostic teaching approach with learners in their own contexts." (International Reading Association, 2006, p.1)

Pratham in India applies the CAMaL (Combined Activities for Maximized Learning) approach which is aimed to a specific group of children (Banerji \&Walton, 2011) "which are organized by ability level, has clear learning goals, uses appropriate teaching-learning activities"(p.1). Progress is assessed by ongoing simple measurement of children's ability to read, write, comprehend and do basic arithmetic and solve problems.

In addition to master the pedagogical techniques, an important component of the teacher's training at the Remedial Centers in Rwanda was for teachers to have an understanding and know how to address not only the learning but also the psychological difficulties of their students who have been out of school, many of them orphans, victims of conflict and coming from different social backgrounds. Teachers were encouraged to show empathy towards the children and make the school experience enjoyable for their students (Kanamugire \& Rutakamize, 2008). In Brazil, the Acelera Brasil program, guides teachers to include activities to boost students' self-esteem and to assure them that they are capable to improve their performance (Instituto Ayrton Senna, 2011).

\section{How much time is needed for pre- or in-service training?}

Generally pre-service training for tutors, volunteers or other para professionals is relatively limited, therefore their instruction requires more supervision and administrative support to be effective. These additional arrangements may be worth the effort as argued by Chabbott (2007) since volunteers may be more receptive to new pedagogies than the regular teachers, therefore better able to implement new and possibly more effective methodologies they learned in their training. In India volunteers with a secondary education and sometimes less were trained for about 4 to 15 days to teach students basic literacy and numeracy skills using a 
simple methodology and low-cost materials and by training instructors who can be secondary school graduates (or less) can be trained. ${ }^{17}$

In Ghana, teachers who were hired to give supplemental language support in the early grades (LLIL project) receive training for about two to three weeks each year in addition to attending several in-service training programs throughout the year (DeStefano, Duplas \& Hartwell, 2007). However, there is no evidence of how much of what they learned in their classrooms and if it has resulted in learning improvements.

\section{How to plan for support, monitoring and evaluation?}

Ongoing support of teachers and instructors need to be available in a regular basis to sustain remedial interventions. Feedback from teachers and others involved can provide valuable information to address implementation obstacles. . Some lessons can be learned from a descriptive study of the implementation of one widely used intervention in the United States for struggling readers-READ 180-in the United States. For this study, middle school principals and teachers from five urban districts answered questions regarding what factors at the district or school level contribute to or hinder on-model implementation. They also share their views on what conditions need to be in place to sustain support and buy-in for the programs. Factors that contributed to successful implementation include teacher's training in READ 180 and inservice training, accurate student placement, and appropriate criteria for exiting the program (Salinger, Moorthy, Toplitz, Jones, \& Rosenthal, 2010). Recommendations for improving the program emphasized providing in classroom support to teachers, coaching, and opportunities for collaboration and communication.

\section{How to provide feedback for students and teachers?}

In Remedial Centers in Rwanda aimed to reintegrate over aged out-of- school children into the regular classrooms, teachers are trained to interact more students and allow more time for classroom participation. The teachers were encouraged to assess the pupils' achievements and pay more attention to corrective action to make the learning more operational. Finally, to strengthen partnership in education, the teachers were invited to collaborate with their colleagues, the children's families and the NGOs that had started this type of training (Kanamugire \& Rutakamize, 2008).

In Brazil, public schools have a support system in place where principals and pedagogical coordinators support teachers who are in the accelerating classes or who provide remedial education as part of their contract (Bonn, 2011).

\footnotetext{
${ }^{17}$ From J-PAL http://www.poverty-action.org/remedialeducation/scalingup
} 


\section{How student's learning can be diagnosed and monitored?}

Remedial interventions require appropriate identification of low performing students, knowledge the level their competencies as well as constant measure of their progress during the intervention. Program implementation can be improved based on information teachers get from assessing if students are mastering the material. Teachers applying the Systematic Method for Reading Success (SMRS) in South Africa assessed their students every ten lessons which included for example recognizing letter sounds, blending sounds to recognize words, reading developmentally leveled stories using the letters and words taught, and answering comprehension questions about the stories (Hollingsworth \& Gains, 2009).

Empowering local school committees to hire community teachers and monitor their teaching can maximize the benefits for children. In the Kenya study, the program was found to be more effective when the extra teachers were monitored by the School Management Committees. In schools where they were not trained to do so, regular teachers were coming less often (Duflo, Dupas \& Kremer, 2007).

\section{e. What does the evidence suggest about remedial education and interventions to improve literacy and numeracy in low income countries?}

In general, the evidence suggests that adequate remedial interventions can yield fast and significant improvements. The beneficial effects of remedial education programs is broad based and not just limited to developed countries. Studies from the United States (Slavin, Lake, Davis, \& Madden, 2009) and from developing countries (AIR \& World Education Inc., 2008; Banerjee, Cole, Duflo \& Linden, 2005; Save the Children, 2011) have shown that remedial interventions have had beneficial impacts on reading and math skills. Piper (2009) reveals that interventions which train teachers in techniques that emphasize literacy-implemented in combination with scripted lesson plans, and ongoing support-were able to increase oral reading fluency scores by more than $100 \%$ in South Africa, Liberia, and Kenya. Similarly, in Liberia, which supports teachers in monitoring education quality in its schools based on Early Grade Reading Assessment (EGRA), showed significant improvements from remedial interventions for students in Grades 2 and Grade 3 after only 4 months (Crouch \& Korda, 2008).

Intermediate results from the ESCUP Project in Cambodia showed improved academic achievement of slow learners with near 6,000 children being identified in need of academic support. After three years of implementation, 72 percent of participating schools reported a decline in repetition rates since the baseline year and at least $50 \%$ of students designated as slow learners are promoted each academic year. Promotion rates among failing children reached 68\% in Year 1, 87\% in Year 2, and 66\% in Year 3 (AIR \& World Education, Inc., 2008).

Effects of remedial education programs or similar interventions implemented in low income countries, mainly the ones focusing on students with difficulties in learning how to read, may or 
may not support those findings, and there is a need for rigorous empirical research on the effectiveness of such programs. This may be difficult since many low income countries lack the necessary resources to measure program effects or even have a standardized assessment to provide valid measures of student learning. Where there is some type of assessment of academic support programs, indicators of program success are mainly drawn from of qualitative data such as teacher surveys to report on the program (Luck \& Parente, 2007).

Program effects ${ }^{18}$ are usually measured by pre and post-test of students' reading levels and some also measure math skills. At the end of the intervention results are compared to students' scores at comparison schools where students did not receive the intervention. Considering that scores at baseline are extremely low in poor resourced countries, program effects may be expected to be high. The results of the following programs indicate that when students who do not receive this type of support, they will continue to perform poorly. Even results from students who received the interventions are far from reaching the goal of learning for all.

\section{Low Income Countries - Literacy Boost}

Another intervention that targets low performing children in the early grades and that has gathered some evidence of program effect is Literacy Boost a program implemented by Save the Children in various low income countries. The program aims at improving literacy by using assessments to identify gaps in the five core skills (letter knowledge, phonemic awareness, fluency, vocabulary, and comprehension); mobilizing communities for reading action, and training teachers to teach the national curriculum with emphasis on reading (Save the Children, 2010).

In Malawi, at the end of school year, Grade 4 literacy boost children read an average of $24-26$ words per minute with $90 \%$ and $73 \%$ comprehension accuracy. Still, this is very far from the standard 45-60 words per minute to achieve reading fluency and being able to comprehend text (Abadzi, 2010)

In Nepal, Comparing the end of year scores of the total sample of non Nepali speakers between the Literacy Boost group and the comparison group, the students in the Literacy Boost group did significantly better at letter identification $(p=0.000)$, CAP $(p=0.000)$, and numeracy assessments $(p=0.001)$ (Shresta, Pinto \& Ochoa , 2010). In Pakistan, Literacy Boost students

\footnotetext{
${ }^{18}$ The most common effect size metric for an intervention on academic achievement is the standardized mean difference which is defined as the difference of the mean outcome for the intervention group and that for the control or comparison group. It represents the number of standard deviation units by which the intervention group outperforms the control group. For education research, a widely cited benchmark is that an effect size of 0.25 is required for an intervention effect to have "educational significance" (Bloom, Hill, Black, \& Lipsey, 2008).
} 
scored significantly higher on average, reading 30.92 words per minute correctly while students in comparison school read only $10.25(p=0.00)$ (Save the Children, 2011).

At the end of the school year in Malawi, there was a significant decrease in the number of Standard 2 students who participated in the Literacy Boost ${ }^{19}$ program (Save the Children, 2010) who scored zero in reading fluency, accuracy and comprehension from $95 \%$ and over in the pretest to $66 \%, 68 \%$ and $72 \%$ in the posttest. While these numbers may be still far from what should be expected, most surprisingly is that after a whole year, $95 \%$ to $99 \%$ of students in the control schools continued to present zero scores in their reading skills posttest. Looking at the scores of both Literacy Boost schools and control schools, it is difficult to identify which results are more striking: the improvements due to the program or the dismal results of the control schools.

\section{India - Balsakhi}

Perhaps the best evidence to date on positive effects of large scale remedial education program targeting the most disadvantaged children comes from the randomized evaluation of the "Balsakhi" (meaning children's friend) program in India implemented by the NGO Pratham. The program targeted children in Grades 2, 3 and 4 who were falling behind, specifically children who have not mastered Grade 1 and 2 reading and math competencies, the majority being marginalized children. While results reported a nearly $8 \%$ increase of students in the bottom third of program classes who acquired the basic competencies, it is not clear if these gains will be sufficient enough for the children to achieve the required reading skills to succeed in the formal school system and complete basic education. Overall, test scores for all children increased in treatment schools by 0.14 standard deviations after one year and by 0.28 standard deviations after two years. In other words, the average student participating in the remedial program will achieve a .14 standard deviation unit above the average student who does not participate in a one year period. A year after the program ended a 0.1 standard deviation test score advantage over the comparison schools persisted.

Another interpretation of these results is the Cohen's classification which introduces the concept of effect size (or practical significance). According to Cohen's classification, the effect sizes of .14 and .01 can be interpreted as very small, with about $58 \%$ of students in the comparison groups scoring below the mean of the treatment group and about $14.7 \%$ overlap in the scores of both groups. Considering that it takes two years of exposure to the program to reach gains of .28, it is still relatively a small effect (Hinkle, Wierma \& Jurs, 2003).

\footnotetext{
${ }^{19}$ Literacy Boost is a program implemented by Save the Children in various low income countries. The program aims at improving literacy by using assessments to identify gaps in the five core skills (letter knowledge, phonemic awareness, fluency, vocabulary, and comprehension); mobilizing communities for reading action, and training teachers to teach the national curriculum with emphasis on reading (Save the Children, 2010).
} 
On the other hand, research results should be considered within the education environment where the program was implemented. Those are test scores measures and it is not known the importance that other variables such as student's increase in motivation or self-esteem that were not included in this study that may impact students' learning. This particular model of remediation which trained community members to deliver intensive help to children falling behind was expanded to another program called Read India implemented rural areas (Banerji \& Walton 2011).

\section{Mali and Niger - SMRS}

In Niger the Systematic Method for Reading Success $(\mathrm{SMRS})^{20}$ provided there months instruction to children in Grade 1.The program also delivered thirty minutes of daily instruction for children in second chance schools (age 9 to 15 years old). In Mali the same program was implemented for 6 months and post -test results showed significant improvements with children from the targeted schools outperforming children from government schools (Plan, 2008).

In Mali, SMRS was taught in Bamanakan to 1295 students in 22 community schools (ages 6-8). To measure the pilot results, the Ministry randomly sampled six SMRS schools (104 students) and six national curriculum or bilingual schools (121 students). Results showed that from a baseline of 0.0 , after only 4 months of instruction, $49 \%$ of students could read 21 or more letters, versus $2 \%$ in national schools after a full year of instruction; $42 \%$ of SMRS students could read more than $50 \%$ of words compared to $2 \%$ of students in national schools; 89.7 (SD 11.22) students in the SMRS schools could read fluently with good comprehension, compared to $41.1 \%$ (SD 9.6) of the students in national curriculum (or bilingual) schools after a full year of instruction. The same reading passage and comprehension question measure was used in both the control and experimental schools.

\section{Chile - Un Techo para Chile}

In Chile, the NGO Un Techo para Chile in collaboration with the government's social strategies has recruited volunteers to offer remedial support after school hours in the slums where children live in extreme poverty. Evaluation results showed that after one year in the program, participant children significantly improved their Spanish and math scores in relation to the comparison group (Contreras \& Herrera, 2005). Unfortunately, particularly for the poor, grade repetition continues to be used in many schools serving the poorest students as a form or remediation. In Chile this strategy has proven to be very ineffective since repeaters are most likely to dropout (Pérez, Saffirio \& Tabilo, 2011).

\footnotetext{
${ }^{20}$ The Systematic Method for Reading Success (SMRS) is adapted from the Systematic Instruction on Phonemes, Phonics and Sight Word method, by John Shefelbein, published by the Development Studies Center, Oakland,CA.. It is built around the teaching of two books totaling 50-70 lessons, taught over a 4-5 month period depending on the language. Each daily lesson lasted 30 minutes (Mitton, 2008).
} 


\section{Ghana - Enlightening the Hearts Literacy Campaign}

Programs such as The "Enlightening the Hearts Literacy Campaign" in Ghana show that it is feasible to implement research evidence supported programs in deprived rural areas such as the country's Northern region, targeting children 8-14 years old in 55 schools. Language teachers were trained in strategies focused on three core areas: literacy, numeracy and writing in mother tongue. The program is taught in local languages and uses child-centered methodology based on the phonetic approach to language acquisition. Evaluation results reveal that over $60 \%$ of learners in P4 to P6 classes were able to acquire basic reading and writing skills within 8 months of the program cycle (CARE International, 2003).

\section{f. What have we learned from remedial interventions that may have contributed to better education outcomes?}

This session lists strategies drawn from the evaluations and reports of the different programs cited in this review considered key factors for contributing to improved learning outcomes of low performing students. While it should acknowledged the diversity of the interventions and therefore they cannot be comparable, these lessons, rather than being prescriptive try to shed some light on certain considerations that may lead to positive results when planning for such remediation types of programs. They can be listed as follows:

- Delivery of quality of in-service training on the intervention, on the new pedagogies or methodologies coupled with ongoing support

- Provision of opportunities for collaboration and communication with all involved in the program

- Give constructive feedback in teacher development activities and supervision used to support teachers rather than being an instrument of control (Lück \& Parente, 2007)

- Train teachers on specific steps of reading instruction

- Collaborative partnerships between the Department of education and program implementers, as the Molteno Institute for Language and Literacy, facilitated access to schools and communications about the program (Hollingsworth \& Gain, 2009).

- In reading interventions, make sure students mastered the first steps such as lettersound association.

- Flexible curriculum

- Tailor instruction building on student's previous knowledge

- Secure funds for program sustainability with strong community involvement and ownership 
- Organize school management committees or other arrangements to monitor implementation

- Timely distribution of pedagogical materials was the factor that most explained the program results (Luck \& Parente, 2007).

- Engagement of all actors involved on the program. For the PARI program in Senegal, positive results of the initial program implementation was attributed to engagement of: department supervisors, school district (IDEN) supervisors, representatives of the National Organization for the Coordination of Vacation Activities (ODCAV), site coordinators and monitors, facilitators, and the beneficiary students as well.

- Plan for successful exit strategies such as support to reintegration to the formal school system or to the appropriate grade level.

While not applicable to many low income country contexts, the United States provides a framework for early detection and correction of learning difficulties called Response to Intervention which may be considered the "golden standard" (Box VV). Some aspects of this approach may be adaptable to a low income country context. 


\section{Box VV. Response to Intervention approach to address early grade reading difficulties}

Response to Intervention or RTI (Allington \& Walmsley, 2007; Fuchs \& Fuchs, 2006; Gersten et al., 2009) is a policy, currently dominant in the U.S., that emphasizes the need to provide low performing students with increasing levels of support to attempt to solve their early reading problems in the context of general education, before involving the special education system.

This type of support is described as three "tiers" of intervention. Tier 1 is support delivered during regular classroom instruction, Tier 2 is almost always small-group instruction, and Tier 3 may be one-to-one tutoring, other intensive services, or possibly assignment to special education.

The interventions become more intense at each tier, which is achieved by (a) using more teacher-centered, systematic, and explicit (e.g., scripted) instruction; (b) conducting it more frequently; (c) adding to its duration; (d) creating smaller and more homogenous student groupings; or (e) relying on instructors with greater expertise (Fuchs \& Fuchs,2006). If students do not show sufficient progress in Tier 2, they are referred to further evaluation to detect if there is a learning disability (Fuchs \& Fuchs, 2006). Schools have the freedom to choose from an array of available approaches to implement Tier 2 or the intensive instruction and studies have been carried out In the US to evaluate their effectiveness. (Ransford-Kaldon, Flynt, \& Ross, 2011)

Niger is an example of a low income country where programs to support low performing students follow a Response to Intervention like framework and its main features are summarized in Box XX. 


\section{Box XX. Remediation in NIGER under the Language and Mathematics Initiative for Early Grades}

\section{Remediation in NIGER under the Language and Mathematics Initiative for Early Grades}

The language arts and mathematics initiative from the National Ministry of Education (MEN) in Niger consists of three main phases:

The diagnostic test phase:

Use of simple tools is to be given at the beginning of every academic year to second through sixth grade students in language arts and mathematics to assess individual competence. The test is administered by the school teachers and the results are communicated to the COGES (Comité de Gestion des Etablissements Scolaires [Committee for Management of Schools] and to the upper level education administrators.

\section{The intervention phase:}

Remediation starts after student levels have been tested. It is expected that no student is to be left behind or forced to drop out of school for not learning. The major practical action taken at the school level is the de-congestioning of the curriculum particularly in the first, second and third grades so as to allow emphasis on the attainment of reading skills and basic mathematics competence. Relevant curricular and pedagogical tools are provided and teachers are trained anew in order to reach this goal. Moreover, extra-curricular activities to support the remediation actions are organized by teachers, former school drop-outs, higher-grade students, local NGOs and COGES members. Resulting pedagogical materials are made available to all stakeholders for potential (re)use.

The evaluation phase:

Evaluation begins with instruments that are ready for use. One entrance and exit test booklet per grade level and subject (language arts and mathematics) and its accompanying teacher guide for every subject are designed for this purpose.

Source: Chekaraou, I. (2010). 


\section{Conclusion}

The more we know about remedial education programs and impacts on reading levels for example, the more the urgency to try apply their techniques to the great number of children who have been educationally excluded.

There is a randomized control trial underway in Ghana to investigate the Teacher Community Assistants Initiative or $\mathrm{TCAI}^{21}$ with remedial education delivered in four different arrangements: remedial education during school hours (group A); remedial education after school (Group B); small groups and reinforcement (Group C); regular teachers without assistants (Group D); and Group $\mathrm{C}$ will be the control group. Five hundred schools will be randomly selected and assigned to one of these groups. The study seeks to address the following questions: a) Will the desired impact on learning outcomes is achieved? And if so is it because of the remedial education or the small class size? b) Will remedial education be more effective during or after school hours? c) Can teachers achieve the same results without assistant? Results may be available after August 2012 (Adu, 2011).

\section{Recommendations}

Professional development for classroom teachers in proven methods should be a major emphasis of programming for low performing students, particularly in reading. There will always be individual children who continue to be low performers despite excellent classroom instruction, but the numbers should be much smaller and the remaining difficulties more tractable when initial classroom instruction has used effective instructional process approaches (Slavin et al, 2009l). More information is needed on how to deliver the best training and support for teachers and others involved so the intervention can be translated into improved learning. Choosing a delivery mode will heavily depend on the available resources since tutoring, for example, can be more costly than teaching in small groups

Scarce resources can be channeled to implement programs at specific points within the primary school cycle where children are more likely to drop out from school such as when transitioning to lower secondary. A more affordable way to provide remediation support can take place after school hours or during summer vacation in the format of "summer camps", delivered by volunteer tutors selected within the community and who receive some training. It does not

\footnotetext{
21 The Teacher Community Assistants Initiative (TCAI) is a project of the Ghana Educational Service on collaboration with the Ghana National Association of Teachers (GNAT), National Youth Employment Program (NYEP) and Innovations for Poverty Action (IPA). The program focuses on the lower half of performers and it is based on Insights from research studies which have been adapted to the country's context. Community assistances are hired though the National Youth Employment Program and trained. Remedial classes last for two hours and are given twice a day (Adu, 2011).
} 
disrupt the regular school day and students may feel more comfortable in a less threatening environment as for example students at risk to repeat a grade have more time to catch up and have the chance to pass.

Remedial education should be part of the teacher education curriculum and in-service teacher training. Therefore teachers, facilitators or other program instructors and supervisors should be: trained in strategies to best identify potential beneficiaries, become familiar with the pedagogic materials and understand how to put them in practice in the classroom, in addition to assess and monitor student learning during the intervention. More information is needed on how to deliver the best training and support for teachers and others involved to ensure that the remedial interventions translates into improved outcomes, so all students may have the opportunity to acquire basic literacy and numeracy skills as well as be less likely to fall further behind and dropout.

Remedial education programs help children to improve learning levels but students need to continue to receive a quality education where their learning gains can be sustained so they will not fall back (Slavin et al, 2009). Efforts for children to be able to achieve reading fluency, for example, should be concentrated in the early grades but at the same time, reading speed must rise consistently through primary and secondary school. This means that students need reading materials for the higher grades in sufficient quantity and through arrangements to take them home (Abadzi, 2010). Emphasis in reading comprehension should continue throughout the middle and secondary grades otherwise even the most fluent readers will fail in the later grades (Biancarosa \&Snow, 2006). 


\section{References}

Abadzi, H. (2010). Reading fluency measurements in EFA FTI partner countries: Outcomes and improvement prospects.

Abadzi, H.(2006). Efficient learning for the poor. Washington, DC: The World Bank.

Abeberese, A.B. Kulmer, T.J., \& Linden, L. (2011).Improving reading skills by encouraging children to read: A randomized evaluation of the Sa Aklat Sissikat Reading program in the Philippines. NBER working paper N. 17105. http://www.nber.org.libproxyimf.imf.org/papers/w17185

Adu, S. (2011). Ghana Teacher Community Assistants Initiative (TCAI). Presentation of the Launch conference of J-PAL Africa. University of Cape Town, South Africa.

American Institutes of Research (AIR), \& World Education, Inc. (2008). ESCUP Final Report. Educational Support to Children in Underserved Populations (Cambodia). http://www.equip123.net/equip1/escup/ActivityMenu/docs/et/Training eng.pdf

Banerjee, A., Cole, S., Duflo, E., \& Linden, L. (2006). "Remedying education: Evidence from two randomized experiments in India," Quarterly Journal of Economics, 122(3), 1235-1264.

Banerji, R., \& Walton, M. (2011). What helps children to learn? Evaluation of Pratham's Read India program in Bihar \& Uttarakhand. Accessed on July 7, 2011 from http://www.povertyactionlab.org/sites/default/files/publications/Read\%20India\%2C\%20What \%20helps\%20children\%20to\%20learn.pdf

Banerji, R., \& Wadhawa, W. (2010). Key features of ASER. Annual Status of Education Report 2005 to 2010. Accessed July 10, 2010 from http://images2.asercentre.org/ASER survey/ASERNuts-Bolts-Sep2010.pdf

Baxter, P., \& Bethke, L. (2009). Alternative education: Filling the gap in emergencies and postconflict situations. Reading, RG: United Kingdom: International Institute of Education and Planning \& CfBT Educational Trust.

Betts, J.R., \& Shkolnik, J.L. (2000). Key difficulties in identifying the effects of ability grouping on student achievement. Economics of Education Review, 19, 21-26.

Biancarosa, G., \& Snow, C. (2006). Reading Next-A vision for action and research in middle and high school literacy: A report to Carnegie Corporation of New York. Washington, D.C.: Alliance for Excellent Education. 
Bohn, Dina. C. V. (2011). School Principal from Escola Estadual Professora Rosentina Faria Syllos, Campinas, São Paulo, Brazil. Correspondence and expert advice. Campinas, SP, Brazil.

Bonvin, P. (2003). The role of teacher attitudes and judgment in decision-making: The case of grade retention. European Educational Research Journal, 2(2), 277-294.

Bray, M. (2007). The shadow education system: private tutoring and its implications for planners ( $2^{\text {nd }}$ edition). Paris: UNESCO.

Bonnet, G. (2007). What do recent evaluations tell us about the state of teachers in SubSaharan Africa? Paper commissioned for the Education for All Global Monitoring Report 2008, Education for All by 2015: Will we make it. UNESCO.

Bloom, H.S. , Hill, Black, A.R. , \& Lipsey, M.W. (2008). Performance Trajectories and Performance Gaps as Achievement Effect-Size Benchmarks for Educational Interventions. MDRC.

Bray, M. (2009). Confronting the shadow education system: what government policies for what private tutoring. Paris: International Institute for Educational Planning.

Brookhart, S. M., Moss, C.M. \& Long, B. A. (2010). Teacher inquiry into formative assessment practices in remedial reading classroom. Assessment in Education, 17 (1), 41.

Cardoso, M. L. C. (2003). Classes de aceleração: conquistas e percalços [Acceleration classes: successes and challenges]. Linhas, 4, (2) , $211-228$. Florianopolis, Brazil.

CARE International (2003). Reaching underserved populations with Basic Education in deprived areas of Ghana: Emerging good practices. Accra and Washington, D.C.: CARE International and USAID. http://www.dec.org/pdf docs/PNACS 0.pdf

Ceraldi, A. (2006). Remedial education helps millions of Palestinian children. UNICEF. Accessed on July 15, 2011 from http://www.unicef.org/education/oPt 31058.html

Chabbott, C. (2006). Accelerating Early Grade Reading in high priority EFA countries. A desk review. Washington, DC: EQUIP1 and AIR.

Chabbott, C. - correspondence and expert advice.

Chekaraou, I. (2010). Improving Quality in Basic Education in Niger: Initiatives, Implementation and Challenges. Teacher Training College (ENS). Université Abdou Moumouni, Niamey, Niger. 
Seminar Title: Issues and challenges concerning the quality of education, and policies and measures Accra, Ghana Tuesday, 19 to Thursday, 21 January 2010. Highgate Hotel, Accra, Ghana. Accessed on October 3, 2010 from http://aadcice.hiroshimau.ac.jp/e/reseach/paper no5-1.pdf

Chisaka, C.B. (2002). Ability grouping in Zimbabwe secondary schools: A qualitative analysis of perceptions of learners in low ability classes. Evaluation \& Research in Education,16(1), 19-33.

Contreras, D., \& Herrera, R. (2005). Reforzamiento escolar para niños de bajos ingresos: ¿Funciona? [Remedial support for low income children: Does it work?]. Universidad de Chile. Accessed on March 10, 2012 from http://www.economia.puc.cl/Sechi2005/herrera rher.pdf

Coptic Orphans (2005). The Valuable Girl Project Program Evaluation Report 2005 (Academic Year 2004 - 2005) Executive Summary. Accessed on June 15, 2011 from www.copticorphans.org

Crouch, L., \& Korda, M. (2008). EGRA Liberia: Baseline Assessment of Reading Levels and Associated Factors. Prepared by RTI for the World Bank. Accessed on June 17, 2011 from https://www.eddataglobal.org/documents/index.cfm?fuseaction=pubDetail\&ID=158

Denton, C. A., Foorman, B. R., \& Mathes, P.G. (2003). Perspective: Schools that "beat the odds". Remedial and Special Education, 24(5), 258-261.

Denton, C. A., \& Mathes, P. G. (2003). Intervention for struggling readers: Possibilities and challenges. In B. R. Foorman (Ed.), Preventing and remediating reading difficulties: Bringing science to scale (pp. 229-251). Timonium, MD: York Press.

DeStefano, J., \& Elaheebocus, N. (2010). Case study. Using Opportunity to Learn and Early Grade Reading Fluency to measure school effectiveness in Woliso, Ethiopia Washington, D.C.: EQUIP2, AED and USAID.

DeStefano, J., Moore, A., Balwanz, D. \& Hartwell, A. (2007). Meeting EFA: Reaching the underserved through Complementary Models of Education. Washington, D.C.: EQUIP2, AED, and USAID.

Dryden-Peterson, S. (2010). Barriers to Accessing Primary Education in Conflict-Affected Fragile States: Literature Review. International Save the Children Alliance.

Duflo, E., Duplas, P., \& Kremer, M. (2009). Peer effects, teacher incentives, and the impact of tracking: Evidence from a randomized evaluation in Kenya. Accessed on June 30, 2011 from http://www.povertyactionlab.org/sites/default/files/publications/61 Duflo Peer Effects and Tracking.pdf 
Duncan, G.J., Claessens, A., \& Huston, A.C., et al. (2007). School readiness and later achievement. Developmental Psychology, 43(6), 1428-1446.

Ehri, L., Dreyer, L., Flugman, B., \& Gross, Al. (2007). Reading Rescue: An effective tutoring intervention model for language-minority students who are struggling readers in first grade. American Educational Research Journal, 44(2), 414-448.

Elabaum, B., Vaughn, S., Hughes, M.T., \& Moody, S.W. (2000). How effective are one-to-one tutoring programs in reading for elementary students at risk for reading failure? A metaanalysis of the intervention research. Journal of Educational Psychology, 92, 605-619.

Fast Track Initiative Secretariat (2009). Reaching out to out-of-school children. Putting Inclusive Education on the Fast Track. Proposal. Washington, DC: The World Bank. Accessed on June 10, 2011 from http://www.educationfasttrack.org/media/library/Themes/vulnerable-groups/FTIEFA OUTREACH PROPOSAL Final.pdf

Fernandes, A. C. S., \& Peluci, C.D. (2011). Alunos Monitores de Informática: uma experiência de inclusão digital e exercício de cidadania [Students as ICT tutors: an experience of digital inclusion and citizenship]. Paper presented at the "VI Seminário Internacional. As Redes Educativas e as Tecnologias: prática/teorias sociais na contemporaneidade" Universidade do Estado do Rio de Janeiro (UERJ) June 6-9, 2011, Rio de Janeiro, Brazil.

Fuchs, D., \& Fuchs, L.S. (2006). Introduction: What, why, and how valid is it? Reading Research Quarterly, 41(1), 927128.

Fredriksen, B. (2009). Rationale, issues, and conditions for sustaining the abolition of school fees. In World Bank \& UNICEF (Eds.), Abolishing School Fees in Africa: Lessons from Ethiopia, Ghana, Kenya, Malawi, and Mozambique (pp.1-41). Washington, DC: World Bank.

Gillies, J., \& Quijada, J. J. (2008). Opportunity to learn: a high impact strategy for improving educational outcomes in developing countries. EQUIP2. Washington, DC, USAID and AED: 24.ISBN.

Georgescu, D., Stabback, P., Jahn, K., Ag-Muphtah, E. \& de Castro, P. (2008). Preparation for Life and Work Comparative Study with a Focus on Basic (Primary and Lower Secondary) Education in Developing African Countries. UNESCO.

Global Campaign for Education- GCE \& Results Educational Fund (2011). Make it right: Ending the crisis on girl's education. Authors.

Gersten, R., Compton, D., Connor, C., Cimino, J., Santoro, L., Linan-Thompson, S., \& Tilly, W. (2009). Assisting students struggling with reading: Response to intervention and multitier 
intervention in the primary grades. A practice guide. (NCEE 200974045). Washington, DC: National Center for Education Evaluation and Regional Assistance, Institute of Education Sciences, US Department of Education. Accessed on September 5, 2011 from http://ies.ed.gov/ncee/wwc/publications/practiceguides

Greenberg, J. (2010). Report on Roma education today: from slavery to segregation and beyond. Columbia Law Review, 110 (4), 919-1001.

Grossen, B. \& Kelly, B. F. (1992a). The effectiveness of Direct Instruction in a third-world context. International Review of Education, 38, 81-85.

Grossen, B. \& Kelly, B.F. (1992b). Using Direct Instruction to improve the effectiveness of teachers in South Africa. South African Journal of Education, 12, 143-147.

Hayward D, Das J. P., \& Janzen, T. (2007). Innovative programs for improvement in reading through cognitive enhancement: a remediation study of Canadian First Nations children. Journal of Learning Disabilities, 40(5):443-57.

He, F., Linden, L. L., \& MacLeod, M. (2009). A Better Way to Teach Children to Read? Evidence from a Randomized Controlled Trial. Accessed on February 20, 2011 from http://www.povertyactionlab.org/publication/effects-school-libraries-language-skills-evidencerandomized-controlled-trial-india

Hollingsworth, S., \& Gain, P. (2009). Integrated Education Program. The Systematic Method for Reading Success (SMRS) in South Africa: A Literacy Intervention Between EGRA Pre- and PostAssessments Lessons Learned from SMRS Mastery Tests and Teacher Performance Checklists. Research Triangle Park, North Carolina: RTI International.

Houtveen, T., \& van de Grift, W. (2007). Reading Instruction for Struggling Learners. Journal of Education for Students Placed at Risk, 12(4), 405.

Idol, L. (2010). Reading Success. Validation of a Specialized Literacy Program (1978-2007). Remedial and Special Education, 31(2), 97-115.

Instituto Ayrton Senna (2010). Programas. Acelera Brasil. Accessed on September 10, 2011 from http://senna.globo.com/institutoayrtonsenna/programas/programas acelerabrasil.asp

International Reading Association (2006). Diagnostic teaching for primary level schooling. Facilitators guide. IRA/UNESCO.

Invernizzi, M. (2001). Improving children's reading ability through volunteer reading tutoring programs. Washington, DC: NGA Center for Best Practices, Educational Policy Studies Division. 
Kanamugire, C., \& Rutakamize, J. (2008). The remedial program for out-of-school and drop-out children in Rwanda. Prospects, 38, 237-246.

Keller, T. A., \& Just, M. A. (2009). Altering Cortical Connectivity: Remediation-Induced Changes in the White Matter of Poor Readers. Neuron, 64 (5), 624-631.

Lewin, K. M. (2007). Improving Access, Equity and Transitions in Education: Creating a Research Agenda, CREATE Pathways to Access, Research Monograph No 1. Brighton: University of Sussex.

Lipson, M. \& Wixon, K. (2004). Evaluation of the BTL and ASTEP Programs in the North, Eastern and Volta Region of Ghana. International Reading Association and USAID/Ghana.

Lück, H., \& Parente, M. (2007). Aceleração da aprendizagem para corrigir o fluxo escolar. O caso do Paraná [Accelerating Learning to correct school flow. The case of Paraná]. Texto para Discussão N. 1274. Brasília: IPEA.

Lloyd, C.B., Grant, M., \& Ritchie, A. (2008). Gender differences in time use among adolescents in developing countries: Implications of rising school enrollment rates. Journal of Research on Adolescence, 18(1), 99-120.

Mathes, P.G., Denton, C.A., Fletcher, J.M. , Anthony, J.L., Francis, D.J., \& Schneider, S. (2005). The effects of theoretically different instruction and student characteristics on the skills of struggling readers. Reading Research Quarterly, 40(2), 148-182.

Mathes, P. G., \& Denton, C. A. (2002). The prevention and identification of reading disability. Seminars in Pediatric Neurology, 9, 185-191.

Mitton, G. (2008). Success in Early Reading Pilot project in Mali and Niger Implementation report GAD MLI0080 \& NER064. PLAN International.

National Reading Panel (2000). Teaching children to read: An evidence-based assessment of the scientific research literature on reading and its implication for reading instruction: Reports of the subgroups. Washington, DC: National Institute of Child Health and Human Development.

NCES, The Nation's Report Card: Reading 2007; NCES, 12th-Grade Reading and Mathematics 2005.

PARI Senegal (2011). Rapport Bilan de la Mise en CEvre du PARI [PARI Implementation Report]. Partenariat pour l'Amélioration des Rendements Internes à l'Ecole Elémentaire. Senegal Ministry of Education and The World Bank.

Pérez, I, Saffirio, I., \& Tabilo, I. (2011). Educación en campamentos. Nuevos elementos para debates [Education in slums. New elements for debate].Dossier CIS \#1. Cientro de Investigacion 
Social. Un Techo para Chile. Accessed on March10, 2012 from http://issuu.com/revistacis/docs/educacionencampamentos?mode=window\&backgroundColor $=\% 23222222$

Placco, V. M., de André, M. E., \& de Almeida, L. R. (1999). Estudo Avaliativo das Classes de Aceleração [Acceleration Classes Evaluation Study]. Cadernos de Pesquisa , 108, 49-79.

Pierson, L., \& Connell, J. P. (1992). Effect of grade retention on self-system processes, school engagement, and academic performance. Journal of Educational Psychology, 84, 300-307.

Piper, B. (2009), IEP Impact Study of SMRS Using Early Grade Reading Assessment in Three Provinces in South Africa. Research Triangle Park, North Carolina: RTI International.

Pratham (2011). Learning Support Classes. Accessed on July 20, 2011 from http://www.pratham.org/S-10-3-Learning-Support-Classes.aspx

Pratham (2008). Summer Camp Reports 2008. Accessed on June 3, 2011 from http://pratham.org/images/summer-camp-report2007-08.pdf

Ritter, G., Denny, G., Albin, G., Barnett, J., \& Blankenship, V. (2006). The Effectiveness of Volunteer Tutoring Programs: A Systematic Review. Campbell Systematic Reviews.

Salinger, T., Moorthy, S., Toplitz, M., Jones, W., \& Rosenthal, E. (2010). Implementation matters: Systems for success. A descriptive study of READ 180 in urban middle schools. Washington, DC: American Institutes for Research.

Save the Children (2010). Save the Children's Literacy Boost Results: Malawi. Handout.

Scarborough, H.S. (2001). Connecting Early Language and Literacy to Later Reading (Dis)Abilities: Evidence, Theory, and Practice. In S.B. Neuman and D.K. Dickinson (Eds.), Handbook of Early Literacy Research (Volume 1) (pp. 97-110). New York, NY: Guilford Press.

Secretaria Municipal de Educação de São Paulo (2006). Diretoria de Orientação Técnica. Projeto Intensivo do Ciclo I: Material do professor / Secretaria Municipal de Educação [Administration for Technical Assistance. Intensive Project of Cycle I: Teacher Guides] - São Paulo: SME / DOT, 2006. Accessed August 10, 2011 from http://portalsme.prefeitura.sp.gov.br/Documentos/BibliPed/EnsFundMedio/Ciclol/Pic/Pic Cicl ol 4Ano Material Professor v1.pdf

Shavelson, R. J., \& Towne, R. (Eds.) (2002). Scientific research in education. Washington, DC: National Academy Press. 
Shresta, D. N., Pinto, C. , \& Ochoa, C. S. (2010). Languages and early grades literacy acquisition in Nepal. International Conference on Language Education \& the MDGs. November 9, 2010. Nepal. Accessed on September 20, 2011 from http://www.seameo.org/LanguageMDGConference2010/doc/presentations/day1/DeerghaN.Sh restha-CeciliaOchoa-ppt.pdf

Da Silva, C.S.R. (2007). Os desafios contemporaneos para a alfabetização [Contemporary challenges for literacy]. Educação em Cena , 1, 8 - 22, Instituto Ayrton Senna, Brazil. Accessed on September 20, 2011 from http://senna.globo.com/institutoayrtonsenna/quem somos/publicacoes/educacao em cena/ EducacaoEmCena Julho 07.pdf

Slavin, R.E., Lake, C., Davis, S., \& Madden, N. (2009). Effective programs for struggling readers: A best-evidence synthesis. Baltimore, MD: Johns Hopkins University, Center for Research and Reform in Education.

Slavin, R.E., Lake, C., Cheung, A., \& Davis, S. (2009). Beyond the basics: Effective reading programs for the upper elementary grades. Baltimore, MD: Johns Hopkins University, Center for Data-Driven Reform in Education. Accessed January 11, 2102 from http://www.bestevidence.org/reading/upper elem/upper elem read.htm

Snow, C. E., Burns, M. S., \& Griffin, P. (Eds.). (1998). Preventing reading difficulties in young children. Washington, DC: National Academy Press.

Stockard, J. (2010). Direct Instruction and Reading in Africa. A Comparison of DIBELS Scores of a DI School in Liberia, a Comparison Liberian School, and US Schools. NIFDI Technical Report 2010-1.

UNESCO (2011). Education counts towards the Millennium Development Goals. Paris: UNESCO. Accessed on July 3, 2011 http://unesdoc.unesco.org/images/0019/001902/190214e.pdf

United Nations (2011). Millennium Development Goals Report 2011. New York: United Nations.

United Nations (2009). Millennium Development Goals Report 2009. New York: United Nations.

UNICEF (2011)a. UNICEF Humanitarian Action for Children.

UNICEF (2011) b. Accessed on July 15, 2011 from http://www.unicef.org/education/oPt 31058.html

UNICEF (2010). Good practices handbook. Lessons Learned and good practices in the educational projects in the unstable humanitarian context of North and South Kivu (DCR). UNICEF Japan. 
UNICEF (2007). Belize Country Programme Document 2007-2011. Accessed on July 15, 2011 from

http://www.unicef.org/about/execboard/files/Belize final approved CPD 19 Jan2007.pdf

Vaughn, S., Linan-Thompson, S., Kouzekanani, K., Bryant, D.P., Dickson, S., \& Blozis, S.A. (2003). Reading instruction groups for students with reading difficulties. Remedial and Special Education, 24(5), 301-315.

Vaughn, S., \& Linan-Thompson, S. (2003). Group size and time allotted to intervention: Effects for students with reading disabilities. In B.R. Foorman (Ed.), Preventing and remediating reading difficulties: Bringing science to scale (pp. 299-324). Baltimore: York Press.

Vellutino, F.R., Scanlon, D.M., \& Jaccard, J. (2003). Toward distinguishing between cognitive and experiential deficits as primary sources of difficulty in learning to read: A two year follow-up to difficult to remediate and readily remediated poor readers. In B.R. Foorman (Ed.), Preventing and remediating reading difficulties: Bringing science to scale (pp. 73-120). Baltimore: York Press.

Vellutino, F.R. \&Scanlon, D.M. (2001). Emergent literacy skills, early instruction, and individual differences as determinants of difficulties in learning to read: The case for early intervention. In S.B. Neuman and D.K. Dickinson (Eds.), Handbook of Early Literacy Research (Volume 1) (pp. 295-321). New York, NY: Guilford Press.

Zimmer, R. (2003). A new twist in the educational tracking debate, Economics of Education Review 22, 307-315.

Vadasy, P.F., Sanders, E.A., \& Tudor, S. (2007). Effectiveness of paraeducator-supplemented individual instruction: Beyond basic decoding skills. Journal of Learning Disabilities, 40(6), 508525.

Wanzek, J., \& Vaughn, S. (2007). Research-based implications from extensive early reading interventions. School Psychology Review, 36, 541-561.

Wils, A. (2004). Late entrants leave school earlier: Evidence from Mozambique. International Review of Education, 50(1), 17-37.

Woessmann, L. \& Fuchs, T. (2005). Families, schools, and primary-school learning: Evidence for Argentina and Colombia in an international perspective. World Bank Policy Research Working Paper 3537. Washington, D.C.

World Bank (2011a). Bangladesh - Reaching Out of School Children: P086791 - Implementation Status Results Report: Sequence 14. 
World Bank (2011b). Senegal - Quality Education for All Project - Phase 2: P089254 Implementation Status Results Report : Sequence 09. Senegal - Quality Education for All Project - Phase 2: P089254 - Implementation Status Results Report: Sequence 09.

World Bank (2004). Chile: Decades of Educational Reform Deliver. En breve series, March 2004, No. 44. Washington, D.C.: The World Bank.

World Bank (2004). Education for All: Compensating for Disadvantage in Mexico. Education Notes. Washington, DC.

World Education, Inc. (2010). Second Quarterly Report. Improved Basic Education in Cambodia (IBEC). USAID. 


\section{Annex QQ. Linkage between Remedial Education Programs and}

Education Strategies of Multilateral and Bilateral Agencies

\begin{tabular}{|c|c|c|}
\hline $\begin{array}{l}\text { Development } \\
\text { Agency }\end{array}$ & Education Strategic Priorities ${ }^{22}$ & Linkages to Remedial Education \\
\hline $\begin{array}{l}\text { The World } \\
\text { Bank }\end{array}$ & $\begin{array}{l}\text { Learning for All: } \\
\text { At the country level, strengthen } \\
\text { education systems to achieve } \\
\text { results } \\
\text { At the global level, develop a high- } \\
\text { quality knowledgebase on } \\
\text { education systems } \\
\text { Invest early, smartly and for all }\end{array}$ & $\begin{array}{l}\text { Create mechanisms to address learning } \\
\text { need of students most of risk of not } \\
\text { learning or dropping out including } \\
\text { remedial interventions and assessment to } \\
\text { inform student's learning in basic literacy } \\
\text { and numeracy skills. } \\
\text { Remedial education is more effective in } \\
\text { the early grades to prevent future } \\
\text { repetition or dropout. Remedial } \\
\text { education promotes social inclusion since } \\
\text { students from disadvantaged } \\
\text { backgrounds and poorly resources } \\
\text { schools are the ones in most need of } \\
\text { support }\end{array}$ \\
\hline
\end{tabular}

ADB - Asian Emphasize strengthening quality, Strengthen quality by implementing Development inclusiveness, and relevant skills Bank Adjust subsector priorities while recognizing major differences in education needs across countries

Utilize new and innovative models of service delivery and financing evidence based methods to improve basic literacy and numeracy skills for all students

Subsector priorities must include students at risk of dropping out and out do school students needing to reentry the system depending on country's needs and context Implement innovative approaches to improve education delivery for all students

InterFocus on three main areas over Remedial education should be included as

${ }^{22}$ Source: Education Strategy 2020. HDNED. The World Bank. 


\begin{tabular}{|c|c|c|}
\hline $\begin{array}{l}\text { American } \\
\text { Development } \\
\text { Bank } \\
\text { (IADB) }\end{array}$ & $\begin{array}{l}\text { the next three years: early } \\
\text { childhood development, school- } \\
\text { to-work transition, and teacher } \\
\text { quality }\end{array}$ & $\begin{array}{l}\text { a teacher education so teachers can have } \\
\text { the adequate and evidence based tools to } \\
\text { address low performance }\end{array}$ \\
\hline $\begin{array}{l}\text { DFID - U.K. } \\
\text { Department } \\
\text { for } \\
\text { International } \\
\text { Development }\end{array}$ & $\begin{array}{l}\text { Quality teaching and learning, } \\
\text { particularly for basic literacy and } \\
\text { numeracy skills } \\
\text { Skills that benefit young people } \\
\text { for opportunities of jobs and } \\
\text { growth }\end{array}$ & $\begin{array}{l}\text { Train teachers to implement evidence } \\
\text { based remedial interventions that can } \\
\text { improve reading and math outcomes in } \\
\text { the early grades } \\
\text { Implement second chance programs for } \\
\text { youth who cannot master basic literacy } \\
\text { and numeracy skills to assure they have a } \\
\text { foundation to be able to further their } \\
\text { education }\end{array}$ \\
\hline $\begin{array}{l}\text { AFD - African } \\
\text { Development } \\
\text { Bank }\end{array}$ & $\begin{array}{l}\text { Complete universal enrolment by } \\
2015 \text { and achieve equity between } \\
\text { boys and girls }\end{array}$ & $\begin{array}{l}\text { Remedial education programs that use } \\
\text { evidence based methods to address the } \\
\text { learning needs of students falling behind } \\
\text { will help students falling behind to stay in } \\
\text { school. }\end{array}$ \\
\hline $\begin{array}{l}\text { DDA- Danish } \\
\text { Development } \\
\text { Agency }\end{array}$ & $\begin{array}{l}\text { Enhance access to education that } \\
\text { improves women's economic } \\
\text { opportunities with emphasis to } \\
\text { attain sustainability in states with } \\
\text { fragile situations }\end{array}$ & $\begin{array}{l}\text { Increase the economic opportunities for } \\
\text { women to be teachers and teachers } \\
\text { aides to meet the demand of qualified } \\
\text { teachers and of education delivery that } \\
\text { can reach all students, with attention to } \\
\text { low performers }\end{array}$ \\
\hline AUSAID & $\begin{array}{l}\text { Improve the functioning of } \\
\text { national education systems to } \\
\text { enable more girls and boys to } \\
\text { complete primary school and } \\
\text { progress to high levels of } \\
\text { education }\end{array}$ & $\begin{array}{l}\text { Remedial interventions may lower } \\
\text { repetition and dropout rates by providing } \\
\text { the means for low performers to catch up } \\
\text { and follow the curriculum progress to } \\
\text { higher grades. } \\
\text { Establish clear policies for compensatory } \\
\text { or second chance programs for students } \\
\text { to be able to progress to and complete } \\
\text { secondary education }\end{array}$ \\
\hline $\begin{array}{l}\text { New Zealand } \\
\text { AID }\end{array}$ & $\begin{array}{l}\text { Assist core bilateral partners to } \\
\text { achieve EFA goals }\end{array}$ & $\begin{array}{l}\text { Remedial education programs provide } \\
\text { additional opportunities for girls and } \\
\text { other vulnerable groups to acquire basic } \\
\text { skills to improve their education and } \\
\text { health }\end{array}$ \\
\hline USAID & Equitable access to quality & Students falling behind need access to an \\
\hline
\end{tabular}




\begin{tabular}{|c|c|c|}
\hline & $\begin{array}{l}\text { education and enhance } \\
\text { knowledge and skills for } \\
\text { productivity }\end{array}$ & $\begin{array}{l}\text { education that addresses their learning } \\
\text { needs. The most disadvantages students } \\
\text { need additional support to be able to } \\
\text { acquire the necessary knowledge and } \\
\text { skills to be productive in the labor market } \\
\text { and the community }\end{array}$ \\
\hline $\begin{array}{l}\text { Ministry } \\
\text { Foreign } \\
\text { Affairs } \\
\text { Japan }\end{array}$ & $\begin{array}{l}\text { Improve the comprehensive } \\
\text { learning environment and } \\
\text { strengthen support to } \mathrm{FT}^{23} \\
\text { countries } \\
\text { Promote centers for vocational } \\
\text { training and networks for higher } \\
\text { education. } \\
\text { Promote education in conflict- } \\
\text { and disaster-affected countries }\end{array}$ & $\begin{array}{l}\text { GPE (former FTI) countries will be advised } \\
\text { to select evidence based remedial } \\
\text { interventions that can yield the largest } \\
\text { gains in a cost effective way } \\
\text { Expansion of vocational education to } \\
\text { include teacher training for early grades. } \\
\text { Remedial education is an alternative } \\
\text { education mechanism that can support } \\
\text { education in the context of conflict- and } \\
\text { disaster-affected countries }\end{array}$ \\
\hline $\begin{array}{l}\text { European } \\
\text { Commission }\end{array}$ & $\begin{array}{l}\text { Support basic education as the } \\
\text { foundation for further learning } \\
\text { Reinforce joint work on a whole } \\
\text { sector approach } \\
\text { Make appropriate links with other } \\
\text { sectors and expand the range of } \\
\text { financing possibilities }\end{array}$ & $\begin{array}{l}\text { NGOs and private organizations may } \\
\text { provide financial resources to implement } \\
\text { remedial programs, including teachers } \\
\text { and para teachers training outside of } \\
\text { school hours }\end{array}$ \\
\hline
\end{tabular}

\section{Annex RR. What can be learned from Remedial Education Approaches in the Unites States?}

Taking into account that students from low- income countries may encounter even bigger constraints at school than students in more developed or industrialized countries, including larger classes or high teacher absenteeism, lessons can still be learned from the research in the United States since the majority of remedial programs targeted schools serving disadvantaged, minority, and limited English proficient children. Similar to children from low income countries, the school may be the only place that can offer these children some chance for future success.

\footnotetext{
${ }^{23}$ The FTI (Fast Track Initiative) is now called Global Education Partnership (GPE). For a list of GPE developing country partners refer to: http://www.globalpartnership.org/partners/developing-countries/.Accessed April 26, 2012.
} 
The implementation of several approaches aimed to improve reading for students falling behind have been researched in the United States. While the country context may not reflect the extent of the learning needs of children from low income countries, students with the lowest achievement to who these interventions to improve reading were targeted come mostly from very disadvantaged backgrounds. Further, research based approaches such as Response to Intervention may be used as a high standards reference to guide programs to be implemented in low income countries' contexts.

\section{Review of approaches to address reading difficulties in the early grades in the Unites States}

Researchers in the United States investigated the effectiveness of combining enhanced classroom instruction and intense supplemental intervention for struggling readers in first grade. In addition they explore the efficacy of two interventions to improve reading. Results showed that students who participated in one of the two intensive supplemental interventions, on average, finished first grade better prepared for second grade than students who received only enhanced classroom instruction. Results support the research hypothesis that intervention instruction should be provided in tandem with quality classroom instruction (Mathes, Denton, Fletcher, Anthony, Francis, \& Schneider, 2005).

Slavin et al (2009) wanted to find out what would be the likely impacts of those alternative approaches or combination of approaches aimed at helping low performing readers in the early grades as well as to inquire for whom those models were likely to work and under what conditions. The review indicated that successful programs had a strong emphasis on phonics and that a combination of reading with systematic phonics was most effective. The review selected 96 studies of all types of approaches that have been evaluated as solutions for low performing readers from kindergarten to Grade 5 . To be included in the review, studies had to use randomized or well matched control groups, the intervention had to last at least 12 weeks, use valid measures independent of treatments, had to have at least 15 students and two teachers or tutors in each treatment group. Interventions aimed to address reading difficulties were in the format of one-to-one tutoring, small group tutorials, classroom instructional process approaches, and computer-assisted instruction. The programs reviewed targeted children who were having difficulties learning to read in grades $\mathrm{K}-5$, more specifically children with reading disabilities, children in the lowest 33\% (or lower) of their classes, or any children receiving tutoring or other intensive services to prevent or remediate serious reading problems. Studies could also be from another country but the report had to be in English.

Ritter, Denny, Albin, Barnett, and Blankenship (2006) reviewed 21 articles or reports based on the data from 1,676 study participants in 28 studies that assessed volunteer tutoring programs. They reviewed randomized only field trials published from January 1985 to August 2005 which yielded academic impacts. The programs were aimed at students in grades $K-8$, and only used 
where adult, non-professional (volunteer) tutors. Results from this review showed that these programs can positively influence language and reading outcomes of elementary school students with an average effect size of .30 .

After reviewing longitudinal studies to see if the positive impact of the tutoring programs in the first grade would last in the following grades, Slavin et al. (2009) found that the positive effects of the tutoring program will last if followed up with improvements in classroom instruction throughout elementary school. This means that these programs cannot compensate for poor instruction in the long term.

As for mode of delivery, Slavin et al. (2009) concluded that one-to-one tutoring seems to be the most effective among the reviewed studies. When comparing effects of one-to-one tutoring with small group tutorials, the review suggested that while small group tutorials with a strong phonetic emphasis and extensive training and follow up can be effective (weighted mean $E S=+0.31$ in 20 studies), effects of one-to-one phonetic tutoring by teachers (mean $\mathrm{ES}=+0.69)$ and by paraprofessionals $(\mathrm{ES}=+0.38)$ were larger. Interventions that compared these approaches using similar curriculum (Ehri et al. 2007) or same instructional method (Vaughn, Linan-Thompson, Kouzekanani, Bryant, Dickson, \& Blozis, 2003) also found stronger effects for one-one tutoring than for a small group treatment. Ultimately schools have to consider the cost benefit of one-to-one tutoring programs.

Key findings of the review were summarized by Slavin et al. (2009) as follows:

- "One-to-one tutoring works. Teachers are more effective as tutors than paraprofessionals or volunteers, and an emphasis on phonics greatly improves tutoring outcomes

- $\quad$ Although one-to-one phonetic tutoring for first graders is highly effective, effects last into the upper elementary grades only if classroom interventions continue past first grade.

- Small group tutorials can be effective, but are not as effective as one-to-one instruction by teachers or paraprofessionals.

- Classroom instructional process approaches, especially cooperative learning and structured phonetic models, have strong effects for low achievers (as well as other students).

- Traditional computer-assisted instruction programs have little impact on reading". (p. $114-115)$. 


\section{Annex SS. Remedial programs for out-of-school/over aged children}

\section{Context}

In 2008, 67 million children were out of school. Progress towards universal enrolment has slowed. If current trends continue, there could be more children out of school in 2015 than there are today (UNESCO, 2010).In some countries, such as Brazil, Colombia and the Maldives, a significant proportion of out-of-school children had attended school in the past, but dropped out. Also in Cambodia, Liberia and Zambia, most out-of-school children will be attending school at some point in the near future (UNESCO, 2011).In India, although most states in India have done well in enrolling more children in recent years, the inability of schools to retain those children has continued to be a serious problem and the number of children out of school is falling too slowly (UNESCO, 2010).

Remedial programs have been developed to meet the educational needs of children whose education has been disrupted or delayed. Among the children of primary school age not enrolled in school, 42\% - 28 million-live in poor countries affected by conflict (United Nations, 2011). Refugees and internally displaced people face major barriers to education. In 2008, just $69 \%$ of primary school age refugee children in UNHCR camps were attending primary school (UNESCO, 2010). Not only are more children, in absolute numbers, out-of-school in conflict affected countries (CAFS), but the rate of improvement in enrollment has been substantially slower. Only two conflict-affected fragile states, Cambodia and Myanmar (Burma), are on target to meet EFA targets by 2015 (Save the Children, 2008).

These programs take place outside the formal school system and are usually implemented by NGO's in partnership with the country government. Indicators or outcomes of these programs are mostly quantitative and focus on participation rather than results on learning achievements. Number of students enrolled by level, number of children returning to the formal education system and number of children who continue to the secondary level are some of those indicators. There is no tracking of student's academic achievement once they enter the formal school system.

\section{Examples of Remedial Programs for Out-of-School and "Over aged" Children}

Remedial centers in Rwanda enroll children who have been out of school in Rwanda which serve as a bridge to reintegrate them to the formal education system (Kanamugire \& Rutakamize, 2008). Likewise, Schools for Life in Ghana provide over aged students in nine months the content of the first three years of primary education so they can return to a regular school at the appropriate age for their grade. (DeStefano, Moore, Balwanz, \& Hartwell, 2007).

Indicators or outcomes of these programs are mostly quantitative and focus on participation rather than results on learning achievements. Number of students enrolled by level, number of 
children returning to the formal education system and number of children who continue to the secondary level are some of those indicators. There is no tracking of student's academic achievement once they enter the formal school system.

UNICEF has also implemented the Remedial Classes Project at the Democratic Republic of Congo. By establishing remedial teaching centers from 2008 to 2010, UNICEF initiated the project to respond to the educational needs of a large number of out-of-school children, high dropout rate during the year, and the need to reintegrate demobilized children. The project prepared by UNICEF was implemented by five partners, four local NGOs and one international NGO in coordination with the administrative and educational authorities and local communities. The project targets children aged 9 to -17 year old since a child of 9 years is considered too old to start in the formal school and therefore can only enroll in remedial teaching centers. The Remedial Teaching Centers provide accelerated learning programs which compress six years into three (or two years into one per elementary, middle and terminal degrees. There were 5.499 beneficiaries of the project implemented by BVES (Bureau pour le Volontariat au Service de l'Enfance et de la Santé) and the numbers show this diversity of vulnerability : 4.140 out-of-school children, 586 displaced children, 223 returnee children, 89 demobilized children, 427 street children, 34 children repatriated from Rwanda (UNICEF, 2011).

Promotion of Girls Education and Employment, implemented by CARE International Ghana/Togo/Benin covers: Vo District (rural) and Lome Districts (urban) and targets out-ofschool girls and young women in rural-urban settings between ages 8-24.Local NGOs engaged in the provision of alternate education services. Curriculum is equivalent to formal school basic curriculum. Learning is self-paced and takes place through peer tutoring and small groups. Medium of instruction is in local language for the first three months with French, the national language, introduced in the following six months. After the initial training period of 9 months, beneficiaries have several options; the younger ones may enroll in a three-year accelerated primary education program. Participants in the accelerated program take the national end of primary education examinations for integration into the formal school system. Unsuccessful candidates opt for vocational/apprenticeship training. Post-literacy program has been created to reinforce knowledge acquired during the functional literacy training phase.

\section{Annex TT. Country examples of remedial programs -}

\section{India - Accelerated learning support classes to improve reading and math in the} early grades

Pratham has been implementing the Learning Enhancement Program (LEP) in selected government primary schools to help students to achieve the expected learning levels for their 
grade where every child should be proficient in reading, writing and math skills. The Learn to Read (L2R) classes is one component of the program and consists of an accelerated learning technique to teach children how to read and do basic arithmetic in 4-8 weeks. The technique integrates four types of class activities ("say something; do something; read something and write something") which is based on the principle that when children are engaged in a variety of activities which have implicit interconnections, they make interconnections and this snowball into a larger skill. As most remedial programs, children are grouped by their ability level after being first assessed on their reading and arithmetic levels. All activities are then built from that level onwards. Once the level of the child is determined, the simple L2R technique is used with each child to help improve his/her reading and arithmetic levels.

Learning levels of participating children can increase in less than two weeks according to pre and post test results. Most impressive is that in such a short period of time it is possible that children who didn't know even letters of the alphabet begin reading sentences and those children who could only read words and not sentences managed to achieve reading fluency (Pratham, 2011).

\section{Cambodia- After school remediation}

After the first semester of school, those children who score lower than the average on the semester exams are identified as slow learners and are encouraged by the teachers to attend remediation classes (N.B. This is only one way of identifying slow learners, other criteria may be used depending on the context). Village-based remediation is so named because it takes place in the village (or sometimes the school if there is not an appropriate space in the community). The teacher runs remediation classes for groups of children after school and provides instruction on topics or areas the students are having difficulty with in the classroom. Before teachers can give remedial instruction they must attend a training workshop (in Cambodia this is two days). Workshop topics include: determining lesson content based on student learning needs; learning in small steps; cueing; self-monitoring of progress; using multiple senses for learning; continuous assessment; and immediate feedback on learning. Two representatives per cluster usually attend the training and then provide training for teachers in the cluster. Teachers provide remediation for children for two hours, twice a week. Teachers are remunerated for their services as they are extracurricular activities.

http://www.equip123.net/equip1/escup/ActivityMenu/act-villageremedial.html

\section{Cambodia - Child to Child Activities - peer tutoring}

Child-to-child networks are developed locally to facilitate community initiative and fit the needs of local schools. Opportunities for children in child-to-child networks may take the form of tutoring younger children, assisting a disabled child to get to school, building ramps at schools, 
establishing homework clubs, tutoring, absentee follow-up, or simply talking together supportively.

http://www.equip123.net/equip1/escup/ActivityMenu/act-childtochild.html

\section{Ghana - Schools for Life}

In Schools for Life in Ghana, school is in session for three hours a day, and the program manages to cover in only nine months the language and math instructional objectives for grades 1-3. Between 1995 and 2003, the program enrolled 50,000 pupils; 43 percent were girls. After only nine months of instruction, over 31,000 pupils-62 percent of the total-continued on to grade 3 or 4 in public schools. Curriculum is equivalent to formal school basic curriculum. Learning is self-paced and takes place through peer tutoring and small groups. Medium of instruction is in local language for the first three months with French, the national language, introduced in the following six months. After the initial training period of 9 months, beneficiaries have several options: the younger ones may enroll in a three-year accelerated primary education program. Participants in the accelerated program take the national end of primary education examinations for integration into the formal school system. Unsuccessful candidates opt for vocational/apprenticeship training. A post-literacy program has been created to reinforce knowledge acquired during the functional literacy training phase (CARE, 2003).

\section{Senegal - PARI - Partenariat pour l'Amélioration des Rendements Internes à l'Ecole Elémentaire}

The PARI program aims to improve the internal efficiency of the Senegalese education system in order to improve outcome sin reading and mathematics of students attending the early grades and first year of middle school (Grade 5) and drastically reduce the repetition and dropout rates. A follow up evaluation plan at all levels will be developed by technical experts. The program took place during school vacation in 2010 and 2011 in selected schools from various school districts. The intervention lasts for two months starting from the first week of July. Students go to classes three days per week from 9 in the morning to 1 in the afternoon. The schedule may change depending on the local context. The students' current teachers identify the low performing students that were proposed for the remedial program. Teachers and facilitators received guides in French and mathematics and on classroom management. The average unit cost is approximately US\$20 including "teachers" salaries and training, learning materials, and supervision. There are no student's fees or contribution to the program.

Expected outcomes of the program include:

In terms of access: at least $80 \%$ of selected students should be enrolled in the support program in $\mathrm{Cl}$ (first grade) with $50 \%$ being girls; at least $80 \%$ of selected students in $\mathrm{CM} 1$ ( $^{\text {th }}$ grade) should be enrolled in the program with $50 \%$ being girls. In terms of expected performance, $100 \%$ of students from which $50 \%$ girls, should pass the post test. 
Overall post test results for elementary grades showed that from the 7,510 participant students, 5, 450 were successful (76.62\%) from which 3,134 were girls (57.50\%). Some regions did better than others. As for Grade 5, 81.62\% of participant students in grade 5 were successful.

Some of the challenges faced by program in phase I of the program included: foods in certain communities resulting on site closings; other Summer activities that interfered with student enrollment and with work of the PARI program; the program late start; lack of involvement of school principals and other school personnel; short training time; concentration of some program sites in rural areas. Also there was delay on the distribution of the pedagogical materials. $^{24}$

\section{Chile - Reforzamiento Escolar}

The Reforzamiento Escolar is program implemented by the Un Techo para Chile Foundation, a nonprofit organization that works to implement social programs in the poorest areas of the country. The program expects that the participants will Improve grades in Spanish and math, continue to be in school in the following year, foster good study habits, develop social skills and overall academic improvement. Beneficiaries are children living in selected areas of extreme poverty. They are divided in two groups: the first includes children from $1^{\text {st }}$ to $4^{\text {th }}$ grade of primary school and the second group consists of children from $5^{\text {th }}$ to $8^{\text {th }}$ grade. The program starts by selecting the poorest areas in the city where the program will be implemented are chosen based on the funds available from the foundation. Then, residents are informed about the program and interested families can enroll their children. The foundation does not select the students, and the selection is demand based. Children must reside in the dwelling and be enrolled in school. The instructors are volunteers who have completed at least secondary education, most are university students. Volunteers need to show interest to work with children and to be committed to fulfill the program's requirements. They receive training about the format and content of the program. The sessions are held twice a week from April to November. One session is for math the other for Spanish and each lasts one and half hours. There should be a minimum of two teachers for each group of eight students. As for methodology, the program has been designed by the foundation's multidisciplinary group. A comparison of math and Spanish pre- and post-test scores showed significant improvement after the intervention in relation to the scores from the comparison group (Contreras \& Herrera, 2005). One of the main challenges faced by the program is that the foundation's economic and human resources funds are not sufficient to cover all students who are eligible for the intervention. Program evaluators believe that the teaching of good study habits and

\footnotetext{
${ }^{24}$ Translations by the author from the original report in French.
} 
development of social skills have contributed to student's performance (Contreras, D., \& Herrera, R. $(2005)^{25}$.

\section{Annex VV. Definitions:}

ASER. ASER was conceptualized and designed as a large scale rapid assessment to be done by ordinary citizens. Therefore the design of ASER incorporates the idea that the exercise must be both simple and fast, so that any interested citizen of India can participate. The methods and measurements cannot be very complex, time consuming or costly. Training is imparted to all ASER volunteers. Typically the duration of training is two days and the actual survey also takes two days. For basic reading and math, the same test is given to children between the ages of 5 and 16. ASER is a household survey of children. All questions and assessment tasks are given to children at home The ASER test is a "floor" level test. It assesses whether children are able to do basic tasks in reading and arithmetic.(Banerji \& Wadhwa, 2010).

Dynamic indicators of Basic Early Literacy Skills - DIBELS .A set of procedures and measures for assessing the acquisition of early literacy skills from kindergarten through $6^{\text {th }}$ grade. They are designed to be short (one minute) fluency measures used to regular monitor the development of early literacy and early grade reading skills.

Disadvantaged groups. A disadvantaged group is defined by the particular pattern of denied resources and barriers it faces (rather than the fact of race, or poverty, or sex). A disadvantaged group may face more than one barrier. Some barriers may be more easily surmounted or moved than others. Each group presents its own pattern of disadvantagement and barriers to self-sufficiency; the implied solutions would vary from group to group as well. Overcoming disadvantages, then, means overcoming or removing barriers to self-sufficiency. This can take many forms, depending on the pattern presented, but would include enabling or empowering the group's own efforts to develop the tools or resources needed for its own selfsufficiency. Page 3 http://www.effectivecommunities.com/pdfs/ECP DisadvantagedGroup.pdf

Complementary Education. Complementary education models are defined as programs that organize basic education in regions of developing countries that are least served by the formal education system. The models are complementary because the programs serve to support the formal education system to reach EFA goals, offering students an alternative route to achieving the same educational outcomes as students in the government system. Through the use of a

\footnotetext{
${ }^{25}$ Information from the original report in Spanish was translated by the author.
} 
similar curriculum, the models also assist in integrating students back into the formal system at various entry points. (from Reaching the underserved Page 159).

Alternative Education programs (Baxteer \& Bethke ,2009) define alternative program implementation in two types depending on their main goals. The first aims to improve access to children not enrolled in the formal system due to gender, ethnicity or geographical location. More specifically those programs may apply the formal curriculum and pedagogy but teachers or instructors may not be certified (e.g. by the ministry) and programs may not be officially recognized by the formal government. Alternative programs may use a more learner-center and participatory pedagogy. The second type are programs designed to change behavior with the provision of alternative curriculum by offering non-traditional subjects such as HIV/AIDS which can be integrated or not with the formal school curriculum

Standard Deviation. A measure of how many the score vary from the mean. 


\section{Annex XX. Sample of work plan for remedial instruction in a primary state school in the city of Campinas, Brazil (in Portuguese) \\ PROPOSTA DE TRABALHO-ESTUDOS DE RECUPERAÇÃO PARALELA - 2011}

Resolução SE 92 e 93, de 08/12/2009 e instrução CENP no 1/2010.

\section{Proposta n으묘}

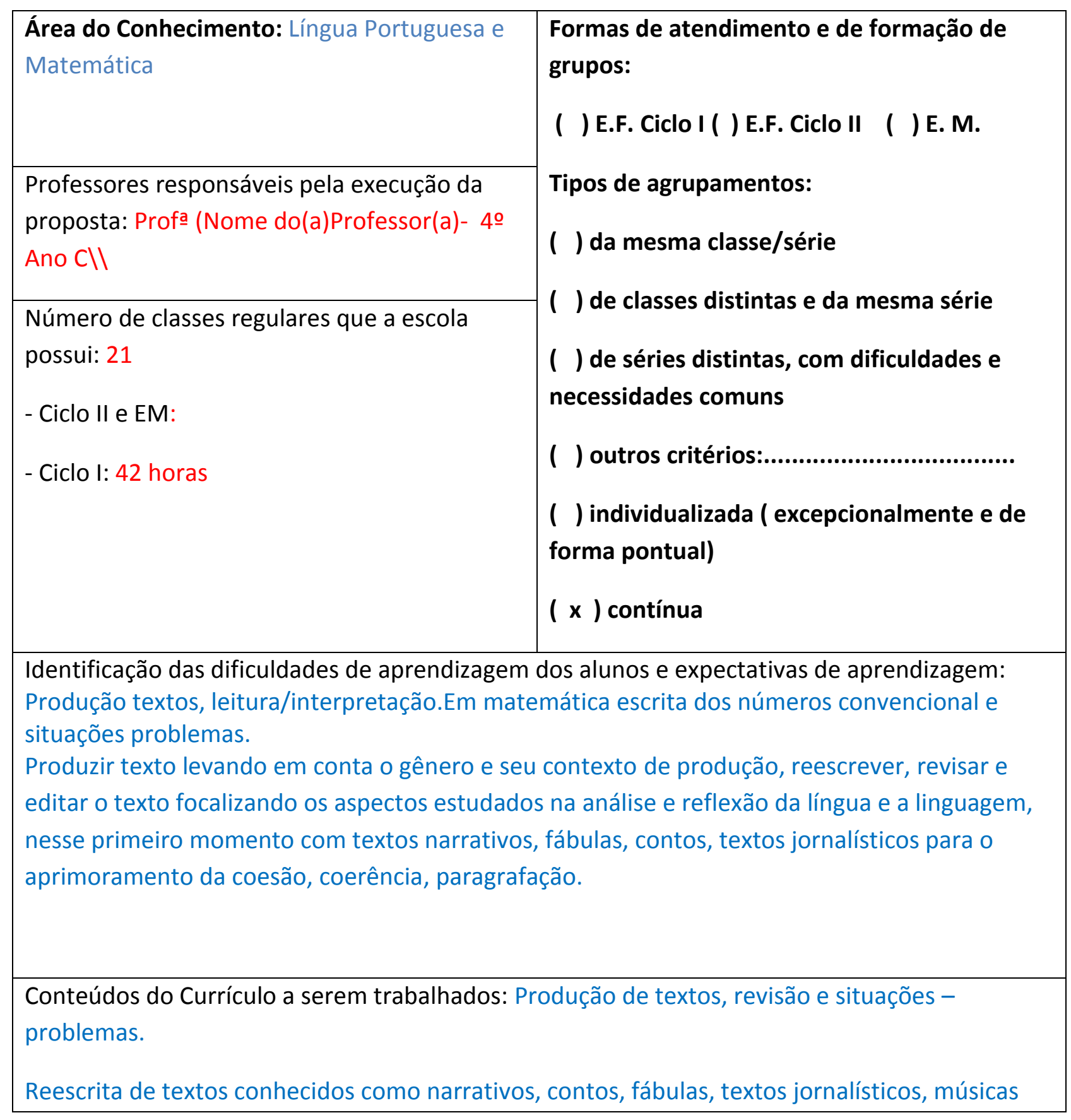


que se sabe de cor, enfocando aspectos da linguagem escrita, reescrita e revisão de textos.

Intervenções pedagógicas: Atendimento individualizado, em dupla e em grupo, com a intervenção do professor.

Trabalho com agrupamentos onde o aluno tenha a oportunidade de rever e refletir sobre o seu próprio texto, fazendo as adequações necessárias, onde o professor é o mediador.

Procedimentos de avaliação: Diariamente através das produções escritas

Horários: $11: 40$ as 12:40 $\quad$ Número de aulas semanais:

Dia(s) da semana: 4a e 5aㅡ feira

02 aulas

Local: Sala de Aula 09

Formas de acompanhamento: Através dos HTPC, Conselho Classe é Série, reunião de pais, horas para estudo e preparação da rotina da recuperação paralela.

Campinas, 01 de março de 2011.

Assinatura do Professor Coordenador

Assinatura do Diretor

Note : the blue or lighter font contains teacher's input.

Source: Bohn, Dina C. V. (2011). School Principal from Escola Estadual Professora Rosentina

Faria Syllos, Campinas, São Paulo, Brazil. 


\section{Annex YY. Links and Resources}

\section{Remediation in Brazil- Teacher's Guide}

Secretaria Municipal de Educação de São Paulo (2006). Diretoria de Orientação Técnica. Projeto intensivo do Ciclo I: material do professor / Secretaria Municipal de Educação. - São Paulo: SME / DOT, 2006. http://portalsme.prefeitura.sp.gov.br/Documentos/BibliPed/EnsFundMedio/Ciclol/Pic/Pic Cicl ol 4Ano Material Professor v1.pdf

Remediation Cambodia in Khmer from the ESCUP program - 2005-2008 http://www.equip123.net/equip1/escup/ActivityMenu/docs/remediation khm.pdf

\section{Intervention Programs in the United States}

Read 180 (USA) - READ 180 was used as an intervention program for fourth to twelfth-grade students who were reading below proficiency. Texas Assessment of Knowledge and Skills (TAKS)Reading and Scholastic Reading Inventory (SRI) data, along with teacher recommendations and grades, were used to identify and place students in the program.

\section{Response to Intervention - Diagnosis}

DIBELS (2008). DIBELS data system: Using data to improve achievement for each and all. https://dibels.uoregon.edu/

Gersten, R., Compton, D., Connor, C., Cimino, J., Santoro, L., Linan-Thompson, S., \& Tilly, W. (2009). Assisting students struggling with reading: Response to intervention and multitier intervention in the primary grades. A practice guide. (NCEE 200974045). Washington, DC: National Center for Education Evaluation and Regional Assistance, Institute of Education Sciences, US Department of Education. Retrieved from http://ies.ed.gov/ncee/wwc/publications/practiceguides

\section{Out of school youth}

Literacy for out of school youth: A program guide. 2010. Produced by Education Development Center, Inc. http://www.equip123.net/docs/e3-Literacy.pdf

Literacy programs for out-of-school youth complement formal school by providing new learning opportunities for young people aged 15-24 who do not have strong literacy skills.

This program guide offers a resource for development specialists initiating or strengthening integrated literacy programs for youth aged 15 to 24 who are not involved in formal education. 
Part III includes a step-by-step process for designing, implementing, and evaluating effective literacy programs.

\section{Remedial education for upper elementary grades}

Being prepared for the next level: See Slavin, R.E., Lake, C., Cheung, A., \& Davis, S. (2009, June). Beyond the basics: Effective reading programs for the upper elementary grades. Baltimore, MD: Johns Hopkins University, Center for Data-Driven Reform in Education.

http://www.bestevidence.org/reading/upper elem/upper elem read.htm 